WIDER Working Paper 2018/149

\title{
Empirical challenges comparing inequality across countries
}

The case of middle-income countries from the LIS database

Daniele Checchi ${ }^{1}$, Andrej Cupak ${ }^{1}$, Teresa Munzi ${ }^{1}$, and Janet Gornick $^{2}$

December 2018 
Abstract: This study presents new empirical results, using microdata from the LIS database, on development patterns in economic inequality for a set of countries that are less covered in the empirical literature, mostly due to the lack of appropriate data. After discussing the main challenges when harmonizing income and consumption microdata from middle-income countries, we focus on Brazil, China, India, Russia, and South Africa, in a comparative perspective, and we compare them with a selection of benchmark middle- and high-income countries. We also run country-level regressions to correlate the inequality measures with selected macroeconomic indicators.

Keywords: economic development, equality, Luxembourg Income Study, middle-income countries, survey data

JEL classification: D31, D63, O1

\footnotetext{
${ }^{1}$ LIS Cross-National Data Center in Luxembourg, Esch-Belval, Luxembourg; corresponding author: checchi@lisdatacenter.org; 2 Stone Center on Socio-Economic Inequality, The City University of New York, New York, USA.
}

This study has been prepared within the UNU-WIDER project on 'Inequality in the Giants'.

Copyright (C) UNU-WIDER 2018

Information and requests: publications@wider.unu.edu

ISSN 1798-7237 ISBN 978-92-9256-591-6 https://doi.org/10.35188/UNU-WIDER/2018/591-6

Typescript prepared by Gary Smith.

The United Nations University World Institute for Development Economics Research provides economic analysis and policy advice with the aim of promoting sustainable and equitable development. The Institute began operations in 1985 in Helsinki, Finland, as the first research and training centre of the United Nations University. Today it is a unique blend of think tank, research institute, and UN agency — providing a range of services from policy advice to governments as well as freely available original research.

The Institute is funded through income from an endowment fund with additional contributions to its work programme from Finland, Sweden, and the United Kingdom as well as earmarked contributions for specific projects from a variety of donors.

Katajanokanlaituri 6 B, 00160 Helsinki, Finland

The views expressed in this paper are those of the author(s), and do not necessarily reflect the views of the Institute or the United Nations University, nor the programme/project donors. 
During the past few decades, the focus in research of income inequality has been predominantly on the high-income OECD countries (see, e.g. Atkinson and Brandolini 2001). More recently, the research has turned to an analysis of top-income shares and its historical development (e.g. Atkinson et al. 2011), again, covering mostly high-income Anglo-Saxon and Nordic countries. The research analysing income inequality in middle-income and developing countries from the Middle East and North Africa (MENA) region, Asia, sub-Saharan Africa, and Latin America is still evolving.

Some of the recent examples, and perhaps the closest studies to ours in terms of the (partial) focus on the middle-income countries, are studies by Alvaredo and Gasparini (2015) and Lakner and Milanovic (2016).

Lakner and Milanovic (2016) analyse global income inequality with international data (combining different household surveys) covering the period 1988-2008. The authors show that the global Gini index reached 70.5 per cent in 2008 and report that the income inequality levels were quite stable over the analysed time period. However, according to their analysis, the inequality levels varied between sub-regions. The lowest income inequality was observed for India, with the Gini spanning from 31.1 per cent in 1988 to 33.1 per cent in 2008. Mature economies experienced a growth in the Gini from 38.2 per cent to 41.9 per cent during the same time period. The highest inequality levels were observed in sub-Saharan Africa, increasing from 53.5 per cent in 1993 to 58.3 per cent in 2008. According to the authors, the fastest increase in inequality during the analysed time period was observed in China, with the Gini index rising from 32 per cent in 1988 to 42.7 per cent in 2008 , overall representing a growth by 33.5 per cent.

Alvaredo and Gasparini (2015), in their detailed analysis, show that national income inequality for developing countries first increased during the 1980s and 1990s and dropped during the 2000s. They also explore possible determinants of changing inequality over time and across countries, finding an inverse U-shaped relationship between the Gini coefficient and log gross national income (GNI) per capita. The authors highlight that despite caveats related to consistency and comparability of microdata from low-income countries, significant progress has been made in measuring and monitoring income inequality and poverty.

Other examples studying income inequality and poverty in developing and middle-income countries are those by Assaad et al. (2016, 2017) for the MENA countries, Piketty and Qian (2009) for China and India, Gasparini et al. (2011) for Latin America, and Novokmet et al. (2017) for Russia.

Regarding the empirical evidence based on the LIS data, Gornick et al. (2009) have been among the first to report inequality trends for the Latin American countries. More recently, the LIS data source has been utilized to demonstrate income inequality and (child) poverty in middle-income countries - for example, by Rasch (2017) and Evans et al. (2018).

The main goal of our study is to update the existing evidence on income and expenditure/consumption inequality, focusing on a set of middle- and high-income countries from Asia (East and South), the MENA region, and Latin America. To present the results in a comparative perspective, we also add high-income countries from neighbouring areas to our analysis. We would also like to share an almost ten-year experience of the LIS Datacentre in harmonizing income and consumption microdata from middle-income countries. This is to show 
the research community all the caveats present in the data, which they should carefully consider when executing cross-country comparative research together on both affluent and less-developed countries.

From the empirical point of view, the main contribution of this study is twofold. First, we extract household- and individual-level income and consumption aggregates for which we compute various inequality measures. Then we merge the computed indicators (country-level averages) with macroeconomic characteristics obtained from the World Bank Indicators database. Our final database covers almost 40 years (from 1976 to 2016), with an unbalanced panel of 20 countries, summing to 150 observations.

By using descriptive and regression analyses, we aim to uncover possible correlations between recent trends in income and expenditure/consumption inequality measures and compositional population statistics related to educational attainment and gender participation in the labour market. We also explore the different magnitudes of correlation between our inequality measures and some institutional indicators capturing countries' economic development. Our empirical analysis updates the findings of Alvaredo and Gasparini (2015) and Lakner and Milanovic (2016) on inequality trends in middle-income countries by analysing more recent years. In the second part, we contribute to the macro-level analysis of Roine et al. (2009), who analyse macroeconomic determinants of economic inequality in a panel of 16 high-income countries.

The paper unfolds as follows. Section 2 discusses the main challenges when harmonizing microdata from developing and middle-income countries. In Section 3 data and variables are presented, while Section 4 describes the applied methodology. Empirical results are presented and discussed in Section 5. Finally, Section 6 concludes and offers policy implications.

\section{The challenges of harmonizing data from middle-income countries}

From its inception in the 1980s, LIS has been historically focused on high-income countries. A pilot project was carried out in 2007 with the collaboration of a team at the World Bank in order to study the feasibility of including middle-income countries in the LIS database. Following the decision to go ahead with this expansion, LIS has made some conceptual adjustments and changes to its list of harmonized variables in order to accommodate more diverse labour market characteristics, social benefit structures, consumption patterns, transnational income flows, and within-country variability.

Among the main changes achieved with the major template revision, which took effect in 2011, the following were mostly aimed at maximizing its applicability at the same time to datasets from both high- and middle-income countries:

- Adjustment of the disposable household income (DHI) concept, such that it also includes non-monetary income from labour and from public and private third parties. The main reason for this enlargement of the DHI concept stemmed from the fact that in many middle-income countries the proportion of non-monetary incomes from own-consumption and social and/or private assistance-based transfers was too important to be left out, and in fact these amounts are much more often available in middle-income countries than in high-income countries, where many data providers do not even collect them, given their irrelevance (see Figure 1, where only the LIS countries that collect non-cash incomes are included).

- Adjustment of the concept of household member to ensure that persons who are physically present in the household but whose incomes do not contribute to the household income 
(namely live-in domestic servants, boarders, and lodgers) are not accounted for in the creation of total household income or the calculation of the equivalence scale.

- Inclusion of a number of living arrangement variables allowing for a better analysis of multiunit/multi-generation households, so that, if available, information on partnership and parenthood of adults outside the nuclear family is retained.

- Inclusion of variables containing information on an array of new topics, including rural/urban indicator, farming activity indicator, type of dwelling, involvement in marginal/informal work, and characteristics of a second job.

After 10 years of harmonizing data from middle-income countries alongside the high-income countries, LIS has acquired some experience with the main challenges, which are typically found when dealing with income microdata from these sources, as discussed below.

Because of the diversity of rural versus urban areas, in many middle-income countries income surveys either only cover urban areas, ${ }^{1}$ where it is easier to capture incomes, or use very different instruments (including different sampling and questionnaires) for the urban and rural areas. This issue proved particularly challenging with the Chinese survey, where the integration of the three different samples (urban, rural, and rural-to-urban migrants) into a unique national sample required some adjustments to the weights and to the variables themselves that risked putting the quality of the resulting file at stake (to the point that for the year 2007, where the issue was particularly severe, LIS decided not to make public the Chinese data). ${ }^{2}$

The definition of housebold membership (and ensuing treatment of individual incomes when creating household-level incomes) is of particular relevance in middle-income countries. Live-in domestic servants are much more common, and are either treated as part of the household (but then there is a risk of double-counting the incomes that they receive from their employer-the household), or are not considered as part of the household (and then there is the risk that they are simply not represented in the sample). Family members temporarily absent are sometimes treated as household members, sometimes not, and it is often difficult to distinguish the two situationsthis is particularly challenging when adults are temporarily absent to work elsewhere (e.g. the case of absent household heads or spouses) as it considerably changes the way their incomes should be accounted for (include their total income as labour incomes or only the part that they send back to the family as remittances). In some cases, individual-level information is also collected about members of the extended family, and it can become difficult to decide whether they are part of the household or not (again with obvious implications for the treatment of their incomes).

Multigenerational households, and more in general large or complex households, are much more common; depending on who is defined as the household head (the older or middle generation in the case of three-generational households), the characteristics of the household—often based on

1 For example, the Continuous Household Survey $(\mathrm{ECH})$ of Uruguay for years antecedent to 2005 only covers the urban population.

2 Another example is the Korean data, which are based on two different surveys with different structures and questionnaires. The first one is the Household Income and Expenditure Survey (HIES), covering all non-institutional households residing within the territory of South Korea but excluding (1) farming households, (2) fishing households, (3) households whose ordinary incomes and expenditures are difficult to separate from business incomes/expenditure (such as households running restaurants, inns, or boarding houses in their dwellings, and households with two or more live-in-employees), and (4) foreign households. The second one is the Farm Household Income and Expenditure Survey (FHES), which covers the farming households (with some exceptions, e.g. single person households). 
the head and its nuclear family-will differ. ${ }^{3}$ In the case of polygamy, many of the usual indicators that are typically based on the head and a single spouse become much more difficult to create.

Figure 1: Household composition in LIS countries

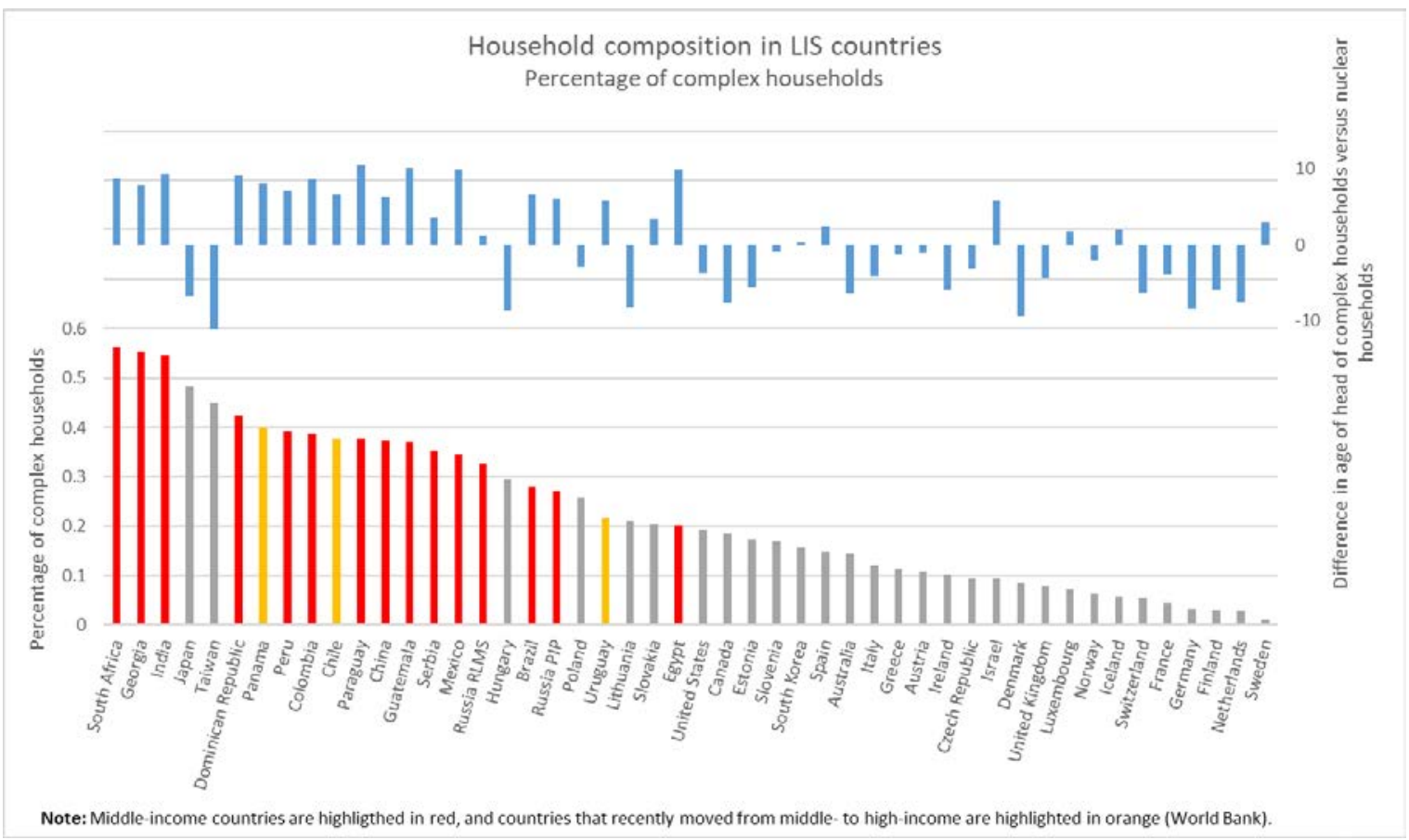

Source: authors, based on data from the LIS database.

When analysing the educational achievement in high-income countries, the information used typically refers to bighest educational qualification achieved (in terms of highest diploma obtained). However, this is not always easy to obtain in middle-income countries, as the information on education typically refers to the highest grade (or level) ever attended rather than the highest level completed; information on literacy is also often relevant; the transformation of this information into highest attained qualification is often very challenging.

When turning to the labour market information, and especially to the employment definition, it should be noted that in many surveys of middle-income countries, the labour market module follows the method of the 'catch-all' question on employment: after responding that he or she does not have a job or does not work, an interviewee is asked a series of questions to determine whether he or she has done any activity in order to help the family (such as cultivating fruits and vegetables, selling products in the street, carrying out services for other persons, helping out in a household business, etc.). Given the large extent to which these activities are performed by women and children in many middle-income countries, considering these activities as ILO employment (under the argument that they fall either under the category of paid work for at least one hour, or as unpaid family work) increases considerably the employment rates, creating large gaps between

3 So that surveys where the head belongs to the older generation will have a disproportionate amount of elderly households, and vice-versa, with obvious implications also for representing (average) educational attainment, the employment situation, and so on. 
population with positive earnings and population employed, as well as potentially creating a bias versus those countries that do not include such questions. ${ }^{4}$

A related point concerns child labour. In most middle-income countries, information about the labour market is collected for children as well, in order to analyse its diffusion. Some surveys have a special section for the children only; in other cases (some of) the same questions asked for adults are also asked for children. In both cases, the creation of a fully comparable labour market participation rate (or employment rate) between those different countries becomes very tricky. In addition, there are typically many questions on unofficial work, non-regular activities, household production, illegal labour (not registered, not covered by social insurance, not taxed) in order to capture some measure of informal labour. These questions are typically very different from survey to survey (often referring to the institutional set up of the country), and are almost impossible to harmonize. As it is extremely difficult to capture and compare the extent of informal employment among the different surveys, one way of proxying these data is to calculate employment rates for the elderly (under the assumption that elderly labour is most often related to informal labour) (see Figure 2).

Figure 2: Employment among the elderly

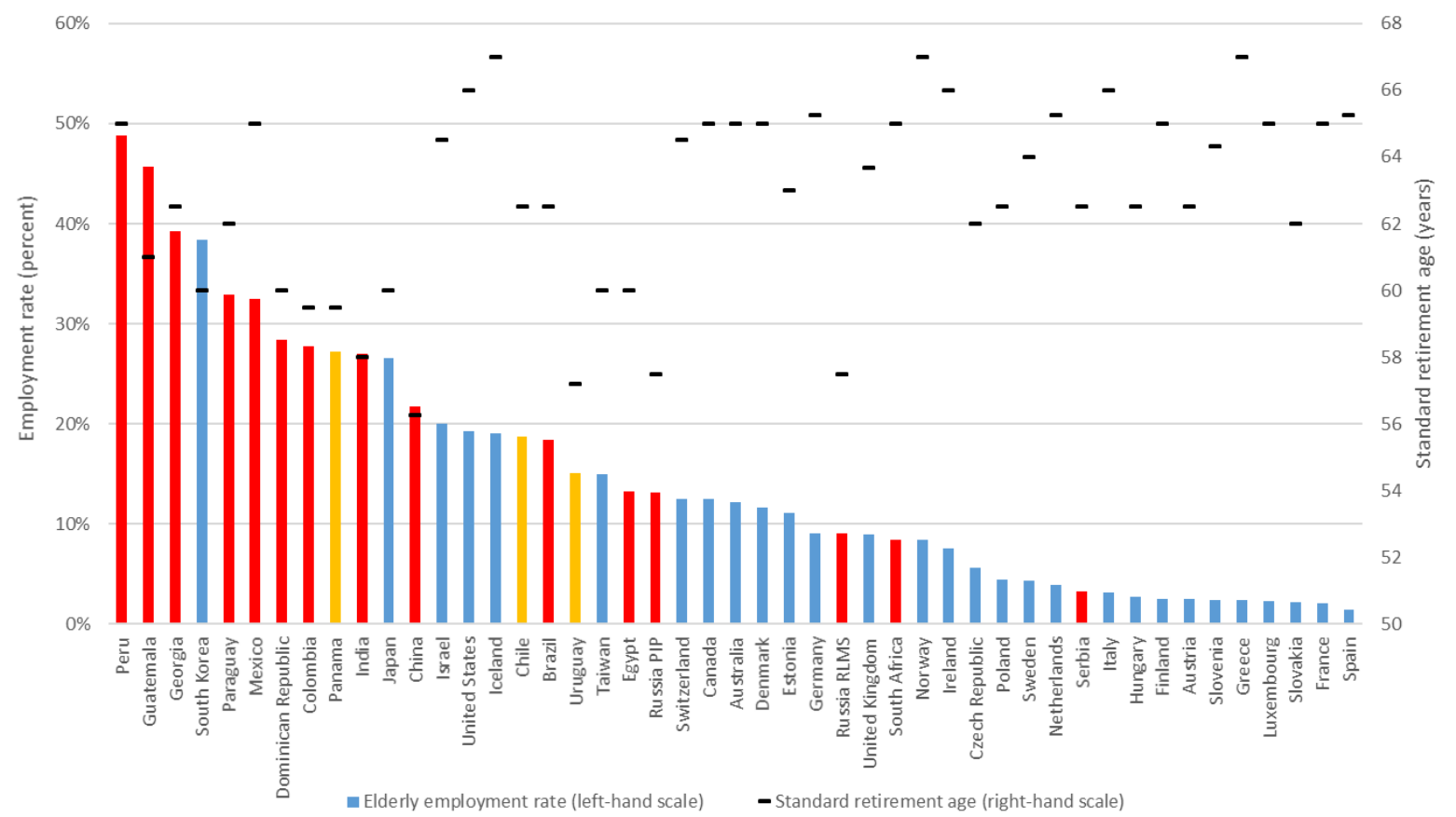

Note: middle-income countries are highlighted in red, and countries that recently moved from middle- to highincome status (World Bank) are highlighted in orange.

Source: authors, based on data from the LIS database.

\footnotetext{
${ }^{4}$ A very clear example of this arises in Peru (with data from the National Household Survey-ENAHO), which, together with Switzerland, is the country that exhibits the highest employment rate of all LIS countries. Like in the surveys of most other Latin American countries, individuals are first asked if they have a job, and if they respond that they do not, then they are asked if they have carried out any activity to help out the family, and the question includes a long list of possible marginal activities. The very high number of persons who answer negatively to the first question and positively to the second implies that the employment mostly consists of marginal employment; it is, however, very likely that the way the question is formulated invites many people who would not have answered positively with a different question, to answer positively.
} 
Finally, the wide extent of persons having multiple jobs makes the harmonization (and hence ensuing comparison) of job characteristics challenging, especially when the questionnaires ask about different types of work in different sections of the questionnaire (e.g. work in a family business separately from work on the farm separately from other jobs); this is troublesome because: (1) it is often not clear if the persons report the same jobs in several sections of the questionnaire, hence incurring the risk of double-counting the jobs; and (2) it becomes difficult to determine which is the main job (Figure 3).

Figure 3: Extent of multiple jobs holders

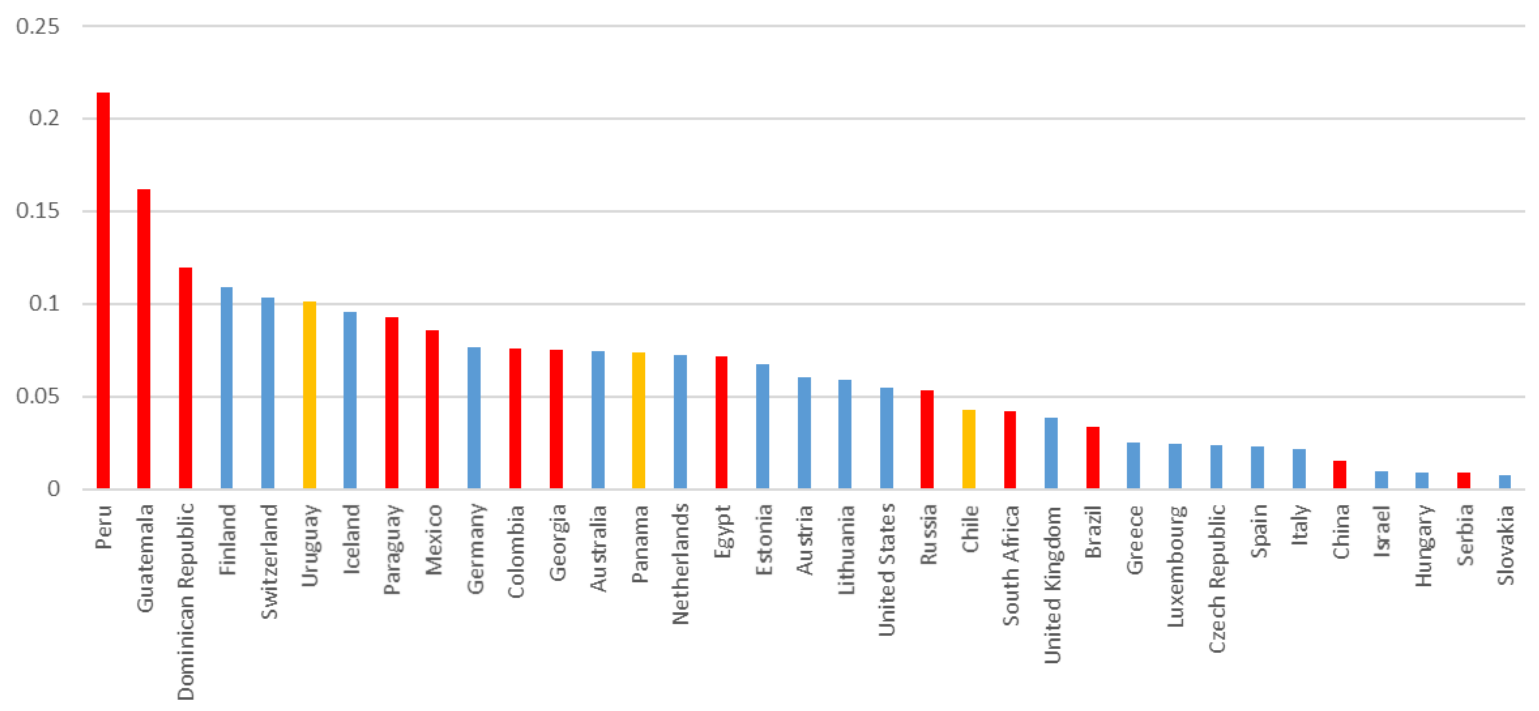

Note: middle-income countries are highlighted in red, and countries that recently moved from middle- to highincome status (World Bank) are highlighted in orange.

Source: authors, based on data from the LIS database.

When looking at the income variables, several issues are at stake when considering middle-income countries. First and foremost, indicators of inequality, poverty, and well-being are still prevalently based on consumption rather than income data, which often implies that income microdata are either non-existent or insufficient for the purpose of calculating robust income indicators (not collected, collected but not provided, collected but not exhaustive to capture the totality of household income).$^{5}$

As already mentioned, the enlargement to the middle-income countries group has been followed by a necessary adjustment of the concept of total disposable income to include also non-monetary incomes from labour (notably own-consumption of products stemming from farming activities) and public and private transfers (notably public and private assistance as benefits in-kind) (Figure 4).

5 The situation with respect to the availability of complete income data is often unclear until one looks at the microdata themselves, and this has often led to situations in which a possibly lengthy process of acquisition of microdata from a new middle-income country has ended with the disposal of the data. This has happened for example with older waves of data from Palestine, where income data existed on paper, but was then not distributed due to its low quality, and with older waves of Egyptian data, where income from self-employment was simply not collected. 
Figure 4: Impact of non-monetary incomes

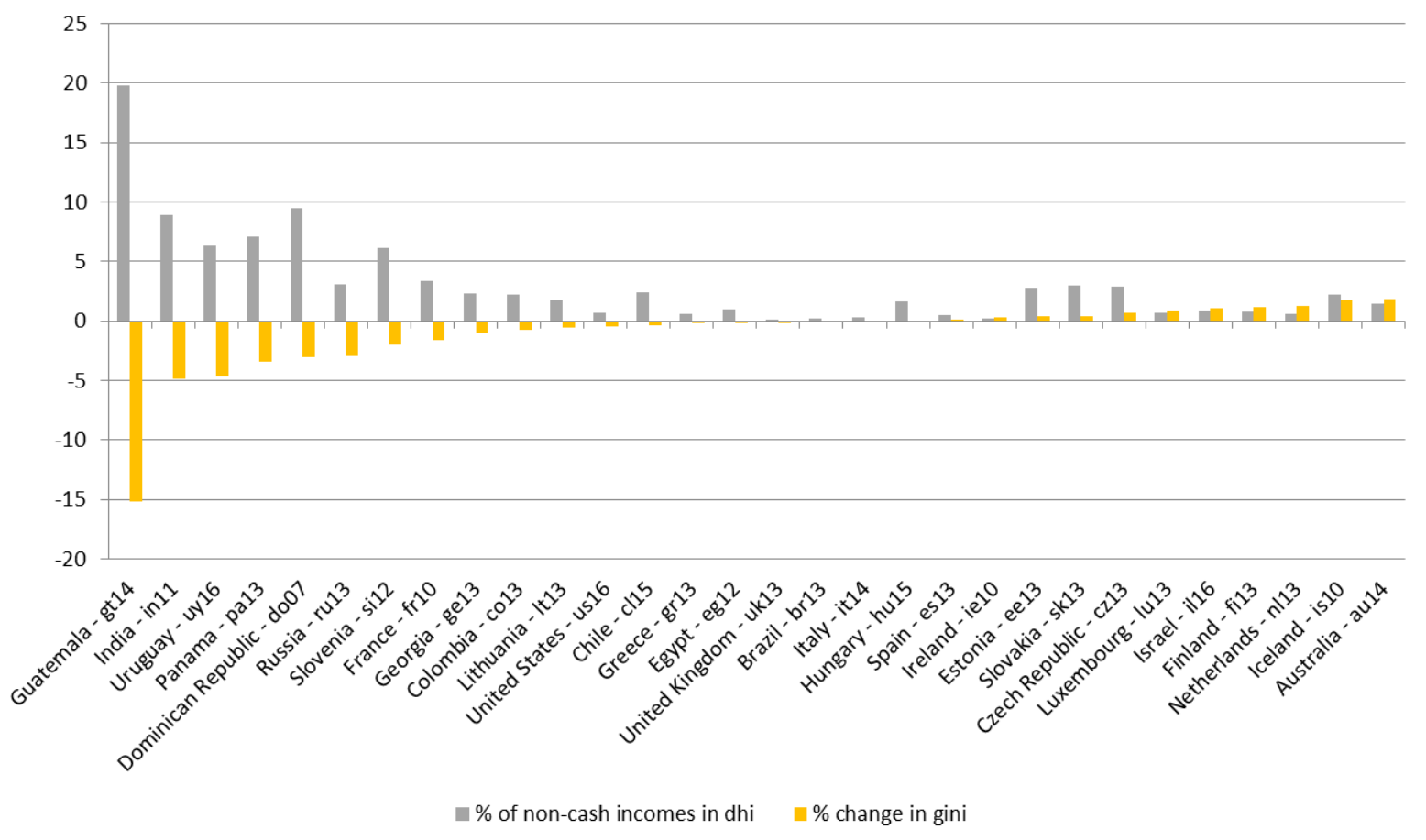

Source: authors, based on data from the LIS database.

Whereas the adjustment was necessary to get a more unbiased picture of the households' standards of living in those countries, the inclusion of those incomes in the data has often proven to be particularly tricky.

The first problem is due to the fact that the coverage of the non-monetary incomes collected by the different surveys differs widely across countries, hence implying a situation in which the comparability is at stake. For example, in surveys that are mostly focused on consumption, the value of most goods and services consumed but not paid for (either because they are ownproduced or because they are received from the employer, the government, charitable institutions, or other private households) is collected with great detail and precision, whereas in other types of surveys the data on the availability of those goods becomes much more scarce.

Another problem arises with the non-monetization of quantities of goods and services; at this stage, LIS has taken the approach to only include those incomes that have been monetized by the data provider, thus increasing the potential bias due to the fact that in some countries, for a purely practical rather than conceptual reason, the final income concept includes more non-monetary incomes than in others.

Somewhat arbitrary assumptions are to be made in the case that non-monetary incomes are collected in different sections of the questionnaire (among the consumption variables, among the household-level incomes from household activities, and among individual-level labour incomes); it becomes clear that those amounts will certainly overlap to some extent, and the creation of a final amount that does not include any under- or over-counting of some income sources proves extremely hard to obtain.

Independently from (but related to) the issue of the non-monetary incomes, another problematic area is that of the selfemployment incomes in general-especially those from farming activities and informal activities. As those incomes are more irregular and difficult to measure by nature, the 
reliability of a total household income variable which is composed in large part by those types of incomes becomes naturally much more difficult. In addition, when it is collected at the household level only (as is often the case in middle-income countries where surveys have specific sections about the household activities), the creation of a comprehensive measure of total individual labour income becomes impossible, hence restricting the possibility of using such an important variable in many analyses (Figure 5).

Figure 5: Labour income availability at the individual level

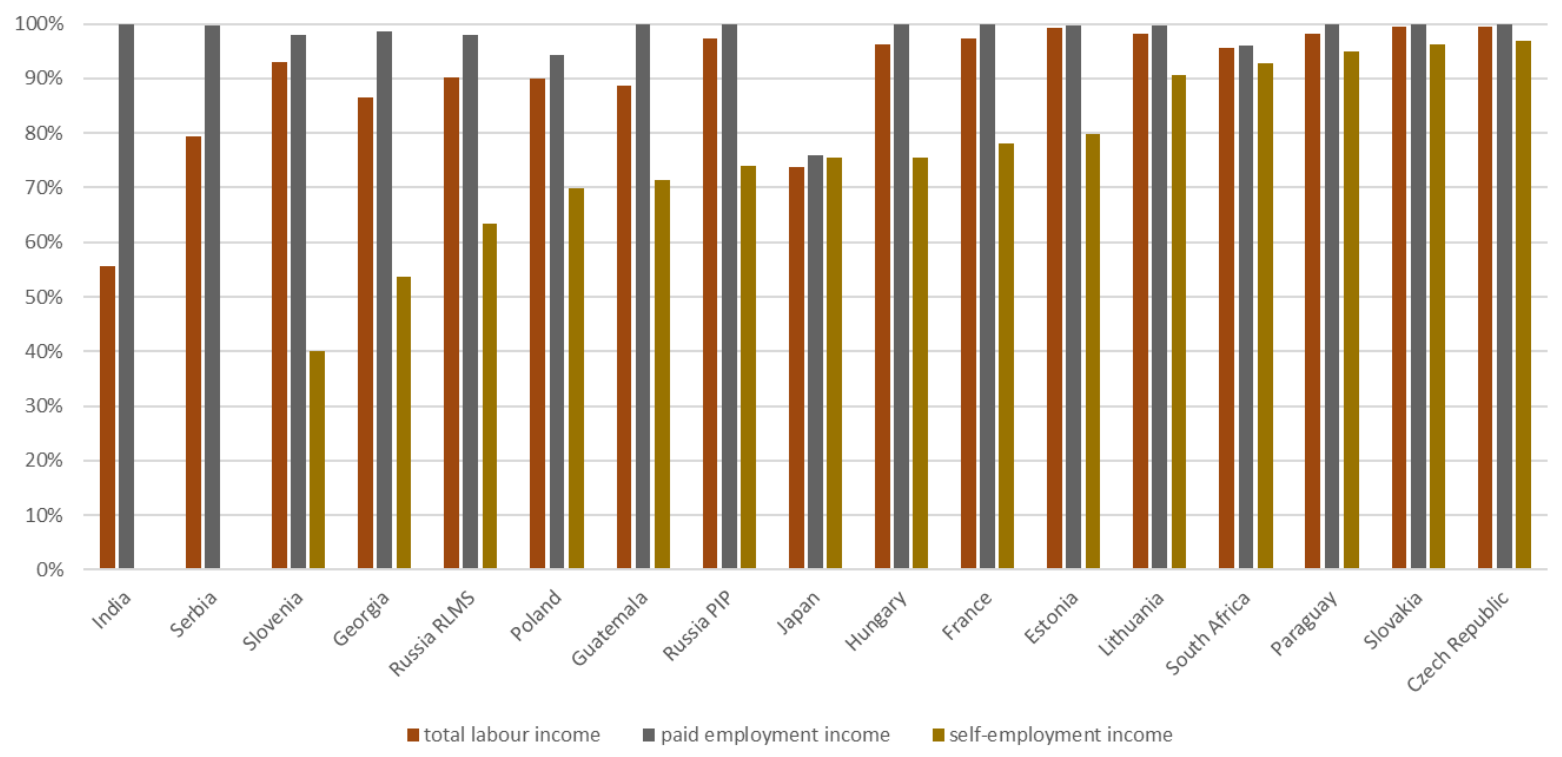

Source: authors, based on data from the LIS database.

Other than the measurement itself of the income, its classification into the different income subcomponents can also become more problematic in middle-income countries. One particular issue refers to the classification of employer-provided pensions and benefits into labour income versus social security: while benefits provided by the employer (such as allowances and subsidies paid together with the basic wage income) have typically been considered as labour income in high-income countries, when moving to middle-income countries it becomes clear that some of those benefits were actually replacing an almost non-existent social security and were thus much closer to social security benefits than labour income. Similarly, the usual distinction between social insurance, assistance, and universal benefits has proven often irrelevant in middle-income countries, where the employment-related benefits stem purely from the willingness of the employer and not from the benevolence of the government, and most of the strictly speaking public benefits are targeted to the very poor.

The treatment of taxes and social security contributions also differentiates middle- from high-income countries (Figure 6). The issue in high-income countries is centred on the difference between the countries/surveys that provide income data gross of taxes and contributions (so-called 'gross datasets') and those that provide the data after such deductions ('net datasets'). More specifically, in the first case all the incomes provided are gross, and the totality of taxes and contributions are deducted from total gross income to obtain the concept of disposable income; on the other hand, for countries that provide each income source already net of taxes and contributions, the sum of all income subcomponents is already net of taxes and contributions, and hence corresponds to the concept of disposable income. As a result, while at the level of total disposable income the variables are perfectly comparable, the comparability is reduced by the fact that at the subcomponent level some datasets provide gross incomes and others net incomes. For middle-income countries the 
challenge concerning the treatment of taxes is rather different. The very low reliance on direct taxes in most middle-income countries makes the above-mentioned issue almost irrelevant, as the difference between 'gross' and 'net' datasets is very tiny. It actually becomes problematic to even simply distinguish the surveys in between gross and net, as the situation is either a mixture of the two (in some cases with only wage income being gross of taxes and contributions and all others net), or simply not being defined at all by the data provider itself. ${ }^{6}$ Several middle-income countries even provide the income data only in gross terms, without indication of the amount of taxes and contributions paid on them, which results in having to simulate taxes and contributions in order to obtain a measure of disposable income comparable to other countries. ${ }^{7}$ In any case, even in the presence of full information on taxes and contributions, the low reliance on direct taxes relatively to the indirect ones in middle-income countries adds a bias to the comparability of well-being indicators based on DHI. If indirect taxes were also taken into account, the true difference between high- and middle-income countries inequality might even be more exacerbated than what the figures show.

Figure 6: Taxes and social security contributions as a percentage of total gross income

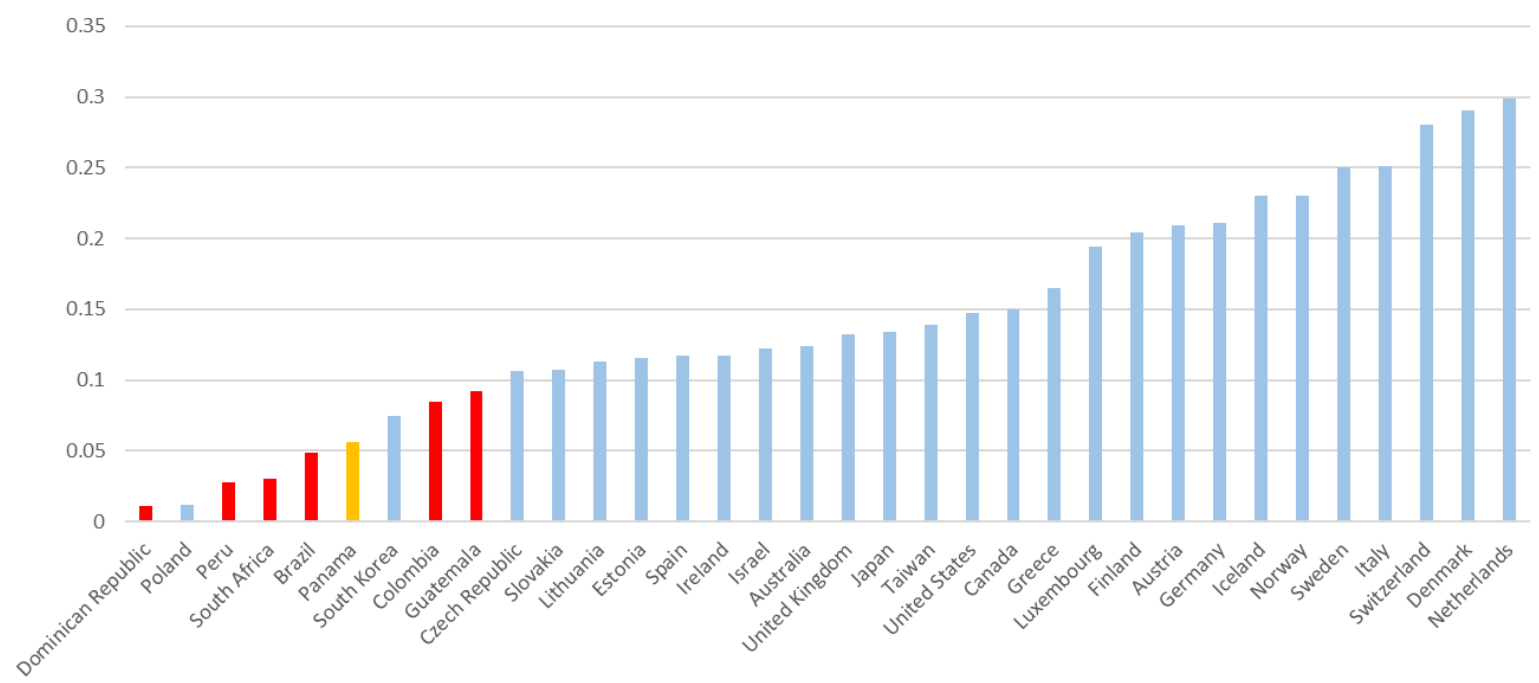

Source: authors, based on data from the LIS database.

From a more technical point of view, an issue that can often become serious, especially in data from middle-income countries (but not necessarily confined to those), is the presence of a large number of observations with missing (or inconsistent) data. When the percentage of households with missing (or zero) total disposable income (Figure 7) goes beyond a certain threshold, ${ }^{8}$ and especially when the data provider does not account for this in the calculation of the weights, the potential bias due to the non-random distribution of those households is large enough to put at

6 This is the case, for example, in India where, given the almost irrelevance of taxes, the data provider does not specify whether the incomes should be reported before or after such deductions, so that the end result is a mix of the two depending on the observations, without any indication as to what the situation is for each observation.

7 This is the case in the National Household Sample Survey (PNAD) of Brazil, the Colombian Great Integrated Household Survey (GEIH), and the Continuous Household Survey (ECH) of Panama.

8 LIS typically uses 10 per cent as the threshold requiring some careful treatment, and 20 per cent as the maximum acceptable threshold for reliable income estimates. 
risk any country-level analysis of the income distribution. ${ }^{9}$ See Figure 7 for an overview of the percentage of households with missing DHI in a selection of LIS countries.

Figure 7: Extent of missing or zero income

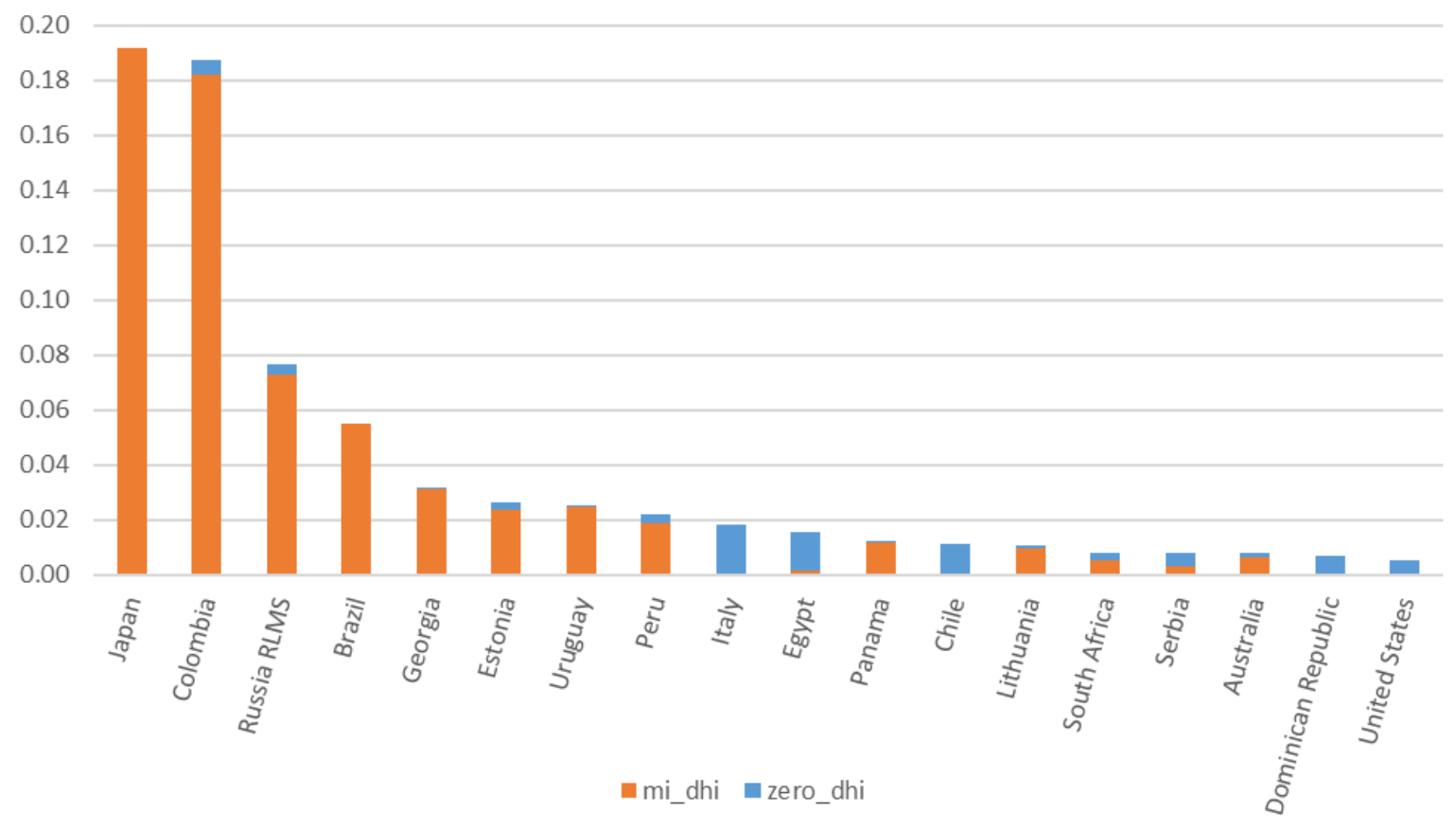

Source: authors, based on data from the LIS database.

All in all, in spite of the efforts made at the various levels of the data production chain (survey conception, implementation, data editing, and data harmonization), there remain some important gaps in order to ensure perfect consistency of the income micro-datasets coming from high- and middle-income countries, and the question of whether those two sets of data can be analysed within the same framework or whether they should be kept separate remains an important one. LIS has adopted the view that a common framework is possible, but cannot stress enough the importance of highlighting all the caveats that go with such an approach.

\section{Data and variables}

\subsection{Dataset}

The present sample of countries is drawn from the LIS database, the largest available income database of harmonized microdata collected from about 50 countries in Europe, North America, Latin America, Africa, Asia, and Australia, spanning over five decades. The biggest advantage of the LIS microdata is the broad coverage of many countries across the world and a large set of standardized variables, making the results directly comparable. LIS datasets contain householdand individual-level data, such as labour income, capital income, social security and private

9 For Tunisia for example, LIS obtained data from the only existing income microdata (the Tunisian Labor Market Panel Survey-TLMPS), but after careful consideration decided not to include it in the LIS database due to a very large portion of the sample having missing household income (about half of the households). 
transfers, taxes and contributions, expenditures, as well as employment conditions and usual demographics.

In our empirical analysis we primarily focus on middle-income countries, including Brazil, China, India, Mexico, Russia, and South Africa. To present the results in a comparative perspective, we consider other middle-income countries (Colombia, Paraguay, Uruguay) and some high-income countries (Chile, Hungary, Israel, Mexico, Poland, Slovenia, South Korea, Taiwan, and the USA) as potential benchmarks. In the regression analysis, we expand the country sample to include other high-income countries (Australia, Austria, Italy, and Peru). The choice of the benchmark countries is mostly influenced by the country's sample length, reliability of the survey data, regional diversity, and finally by the country's economic environment with respect to the core countries (i.e. matching gross domestic product (GDP) per capita, trade openness, financial development, etc.). A comprehensive overview of our sample countries and years available is presented in Table A1.

\subsection{Variables}

Our main outcome (household-level) variables are household pre-tax market income (consisting of labour and capital income), household disposable income, and household monetary consumption, as well as the total individual-level labour income. Note that values in all outcome variables were bottom- and top-coded ${ }^{10}$ and equivalized, applying the square root scale. The covariates, which are further used in the empirical part, include basic information on gender, education, and employment status of individuals. Detailed definitions of the employed microvariables are given in Table A2.

In addition to variables used in the microeconomic inequality analysis, we consider a set of macroeconomic country-level characteristics that have been shown to be significant determinants of economic inequality (e.g., Alvaredo and Gasparini 2015; Davies et al. 2017; Roine et al. 2009). Similarly to previous studies, our considered macroeconomic characteristics include GDP per capita, share of agriculture in the GDP, share of urban households, life expectancy, age dependency ratio, and share of government spending in GDP. A full list of country characteristics along with their definitions is presented in Table A3. A natural question here is what the associations between inequality and such macroeconomic indicators should look like. Following Roine et al. (2009), we summarize the impact of the main contextual variables. First, standard Kuznets theory predicts different inequality levels across a country's development path suggesting an inverse U-shape relationship between GDP per capita and inequality. Standard theory also suggests that the growth of financial markets goes hand in hand with lower inequality. If it comes to trade liberalization, the standard Heckscher-Ohlin predicts that trade openness should favour the rich, hence increasing inequality levels. Finally, central government spending (as a proxy for the welfare state) is believed to equalize incomes of households.

\section{$4 \quad$ Methodology}

In our empirical analysis, we first compute a set of inequality indicators for the income and consumption aggregates, as well as for major population subgroups. Then, we correlate the estimated inequality measures with country-level macroeconomic indicators, which were discussed in the previous section. Here, we acknowledge that in all cases causality may go in both directions,

10 In our case, the values in main outcome variables were bottom-coded at 0 and top-coded at 10 times the median of the corresponding non-equivalized variable. 
and therefore these are to be considered as nothing more than descriptive statistics. In the next two subsections we briefly summarize our methodological framework.

\subsection{Inequality measures}

In this section we describe the inequality measures that we apply to the main outcome variables: household-level disposable income and total consumption, and individual-level labour income. For the reader's convenience, we briefly recall the definition of the main inequality indicators we are going to use in the analysis. Following Cowell (2011), let us consider a population of households (individuals), indexed by $i=1, \ldots, n$ with income (consumption) $y_{i}$; the arithmetic mean of the income (consumption) for the population is given by $\bar{y}=\frac{1}{n} \sum_{i=1}^{n} y_{i}$.

The main inequality indicator that we present through the paper is the Gini index, which can be written as follows:

$$
\text { Gini }=\frac{1}{2 n^{2} \bar{y}} \sum_{i=1}^{n} \sum_{j=1}^{n}\left|y_{i}-y_{j}\right| \text {. }
$$

A second inequality measure that we apply is the Atkinson index, which is given by:

$$
\mathrm{A}_{\varepsilon}=1-\left[\frac{1}{n} \sum_{i=1}^{n}\left[\frac{y_{i}}{\bar{y}}\right]^{1-\varepsilon}\right]^{\frac{1}{1-\varepsilon}}
$$

where $\varepsilon$ represents the weighting parameter measuring aversion to inequality. In our case, we compute the Atkinson index for $\varepsilon$ taking values of $0.5,1$, and 2 . The higher the parameter, the stronger the expression of inequality aversion captured by the index.

The final inequality measure we consider is the mean log deviation index, which can be written as:

$$
\mathrm{MLD}=\frac{1}{n} \sum_{i=1}^{n} \log \left(\frac{\bar{y}}{y_{i}}\right)
$$

and has the advantage of being exactly decomposable in a between-group and within-group component. In our case, we consider groups created out of gender and three educational categories.

In addition to the three inequality metrics discussed above, we also compute some percentile ratios and income shares. The percentile ratio exhibits the proportion of one income group over the other. Instead of analysing the distribution as a whole, it compares two points of the distribution. In our case we compare the average income of the richest 90 per cent of the households (individuals) to the poorest 10 per cent. The income shares measure gives an overview of what share of the total income is held by a certain subpopulation group. In our analysis, we focus on the bottom 50 per cent, top 90 per cent, and 95 per cent of the households (earners).

\subsection{Regression analysis}

In the second stage of our empirical framework, we run a set of country-level regressions in which we correlate the computed (average) inequality measures to macroeconomic indicators capturing 
the country's economic development. We estimate the relationships by the following linear regression:

$$
\text { Inequality }_{i t}=\beta_{0}+\beta \mathbf{X}_{i t}^{\prime}+\delta_{i}+u_{i t}
$$

where the left-hand side variable is a specific inequality indicator estimated for country $i$ in period $t, \mathbf{X}_{i t}^{\prime}$ presents a vector of country-level characteristics including indicators such as GDP per capita, employment rate, educational attainment in the population, life expectancy, etc., along with the corresponding coefficients $\beta$ to be estimated. We also control for country fixed effects $\delta_{i}$ in the regressions. Note that controlling for time fixed effects is more problematic, since the survey years are not coincident among countries (see Table A1).

\section{$5 \quad$ Results}

\subsection{Descriptive analysis}

We start our analysis of inequality trends by showing the inequality levels for a set of BRICS middle-income countries (Brazil, China, India, Russia, and South Africa). We also add figures for the USA as a benchmark country. To cross-check the picture emerging from the LIS database, we also include inequality measures and income shares from external sources: for inequality measures we collected additional data from the UNU-WIDER WIID database, ${ }^{11}$ whereas for income shares, we considered data from the World Inequality Database. ${ }^{12}$

In Figure 8, the first aspect to be considered is that inequality in market incomes is always higher than inequality in disposable incomes, the average difference being around 5 percentage points, with consumption inequality (when available) taking an intermediate value (but in Russia and South Africa). ${ }^{13}$ One might notice that household consumption is covered only for a subset of countries in the LIS database. In Figure 9 we present a scatter plot between the Gini index of household disposable income and the Gini index of household (monetary) consumption. We can observe that the link between the two is quite strong, with a Pearson's correlation coefficient of about 0.87 . This might imply that whenever the information on consumption is not available, we could infer a trend for consumption inequality based on the income inequality data and vice versa.

\footnotetext{
${ }^{11}$ www.wider.unu.edu/project/wiid-world-income-inequality-database.

12 https://wid.world.

13 The average Gini indices for BRICS countries in LIS are 0.51, 0.46 and 0.47 for gross market incomes, disposable incomes and consumption respectively. The corresponding averages obtained from WIID are 0.49 and 0.44 for disposable incomes and consumption
} 
Figure 8: Trends in income inequality (Gini index) in selected middle-income countries (USA as benchmark)

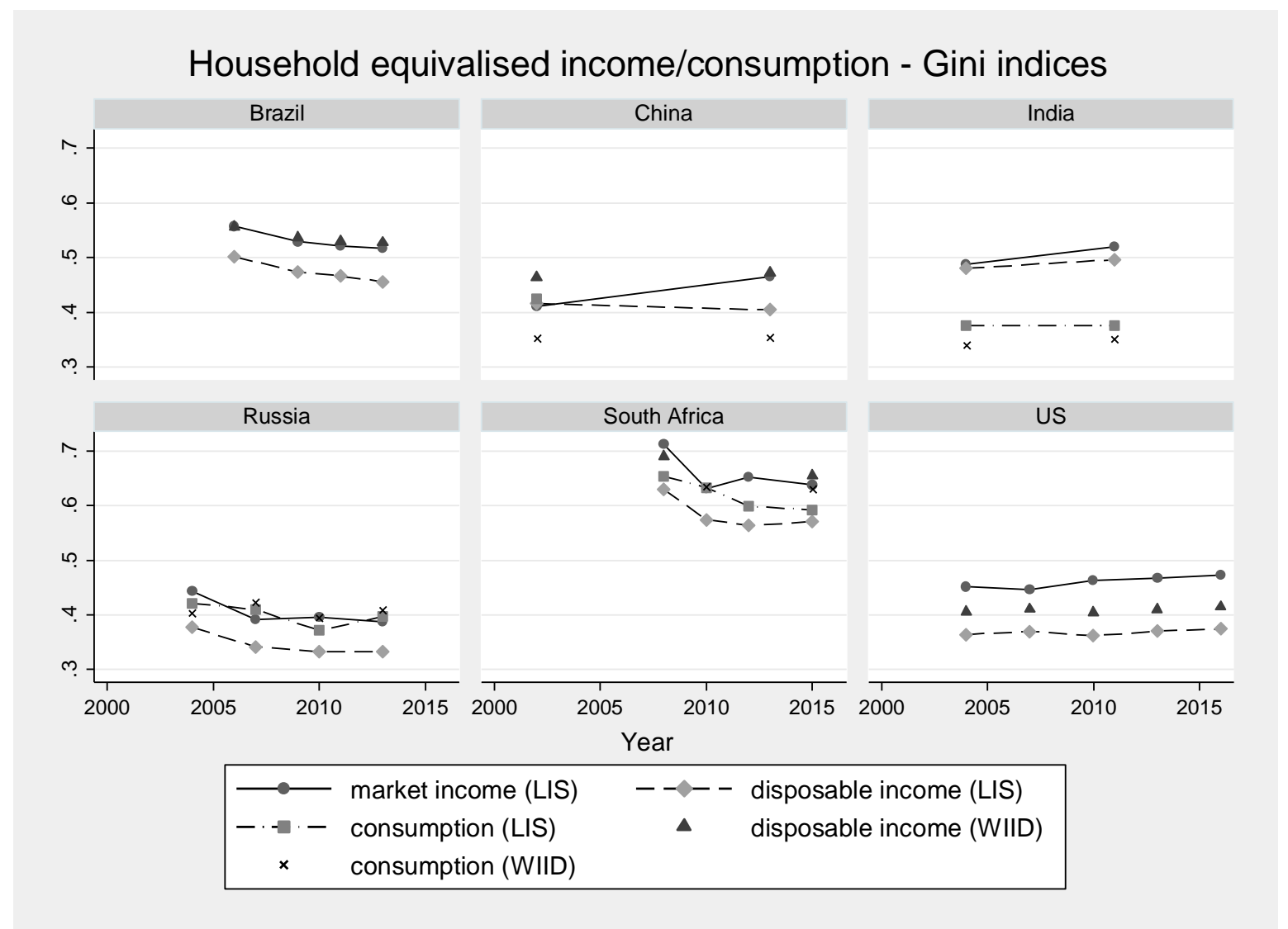

Note: Gini indices obtained from the WIID database are per capita, therefore they exhibit higher levels compared to the equivalized LIS numbers (except India for consumption).

Source: authors, based on data from the LIS database and WIID database. 
Figure 9: Relationship between income and consumption inequality

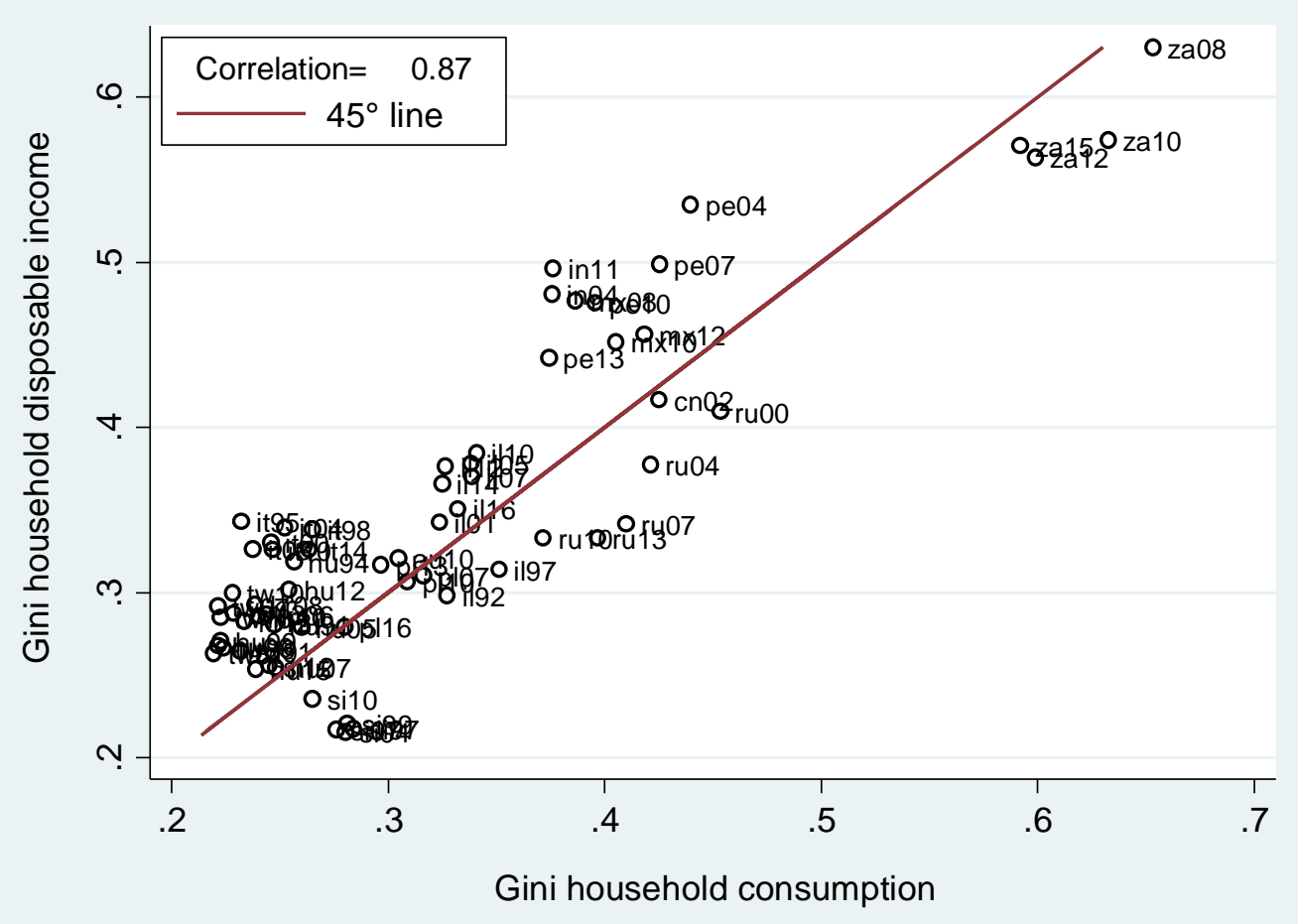

Source: authors, based on data from the LIS database.

Considering now inequality trends, from Figure 8 we observe that inequality is on a declining trend in the case of Brazil: for example, the Gini index of household disposable income declines from around 50 per cent in 2006 to around 46 per cent in 2013. A similar declining trend can also be observed in the figures obtained from the WIID database. The decline in inequality in Latin America is a known phenomenon (see Cornia 2014) that extends to most Latin American countries available in our dataset (see Figure A1). Among the suggested explanations one may consider a drop in the skill premium following an expansion of secondary education, and the adoption of a new development model by a growing number of progressive governments which adopted prudent but more equitable macroeconomic, tax, social assistance, and labour policies. For example, Lustig et al. (2013) argue that overall decrease in income inequality in Latin American countries was dominated by a decline in labour income inequality that occurred due to expansion of employment and hours worked. These changes raised the incomes of, especially, the poor (roughly defined as the bottom half of the distribution), at the expense of the élites (again roughly identified as the top 5 per cent or 10 per cent in the distribution-see Figure 10).

Going back to Figure 8, for China and India we can hardly talk of any trend as there are only two data points available for each country in the LIS database. With this caveat in mind, we observe that in the case of China inequality in market income is on the rise, while the (admittedly limited) redistributive activities of the public sector contained this trend, leading to a constant inequality in terms of disposable incomes: in fact, the Gini index of pre-tax market incomes rose from 41 per cent to 46 per cent between 2002 and 2013, while the Gini index of household disposable income 
spans around 40 per cent. ${ }^{14}$ The rising trend in pre-tax income inequality is confirmed in other studies, though it could hide an even higher peak reached around the year 2008 Jain-Chandra et al. 2018; Ghosh 2012). Income shares observed in Figure 10 suggest that most of the gains from growth accrued to the richest 10 per cent (though LIS data underestimate this share due to inability to capture the top incomes, as detectable when comparing with WIID top incomes data). Contrary to the Latin American experience, differences in educational attainment at tertiary level and the skill premium are identified as drivers of the increase in income inequality (Jain-Chandra et al. 2018).

Figure 10: Evolution of income shares held by households with incomes below the 50th, and above the 90th and 95th percentiles

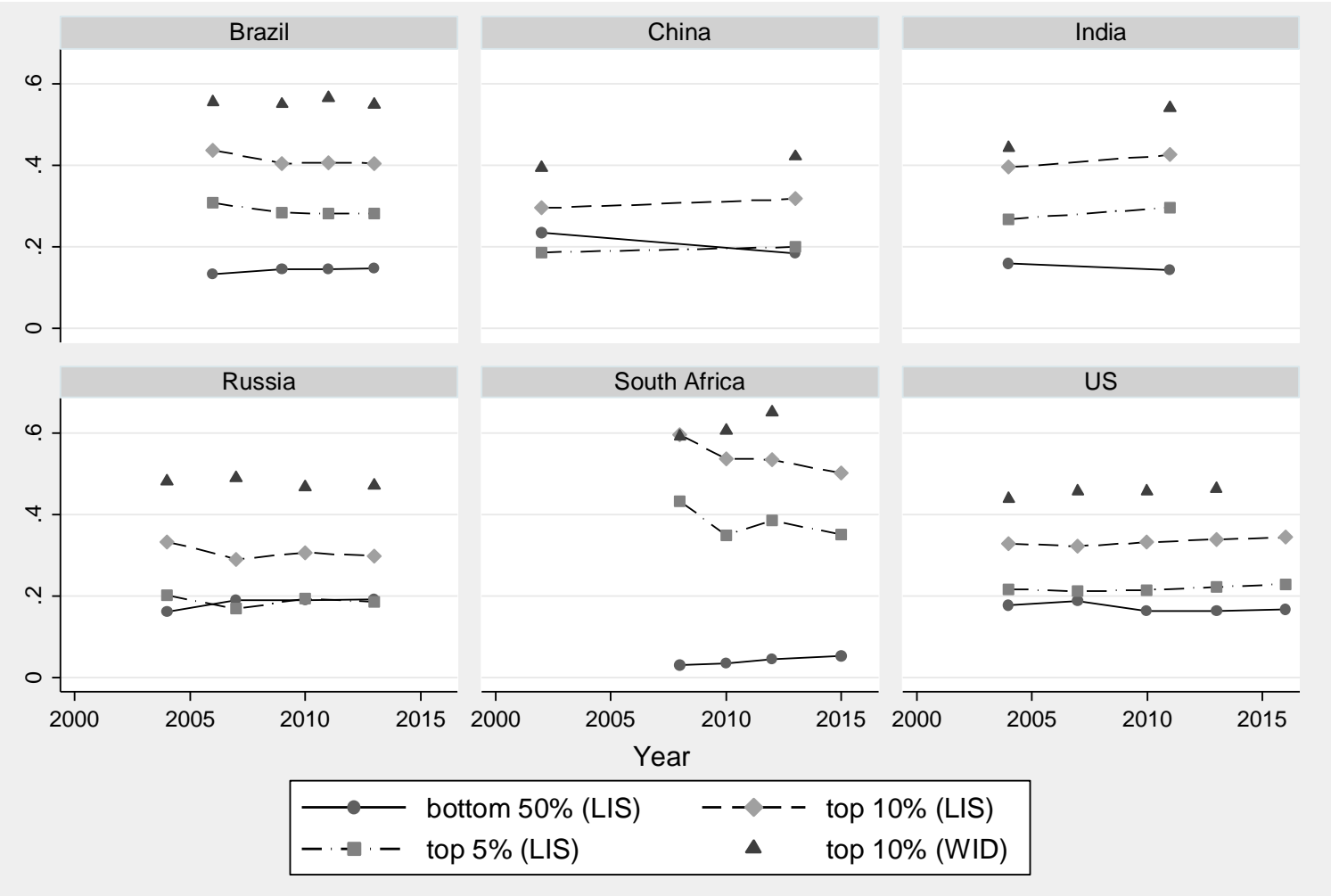

Source: authors, based on data from the LIS database and the WIID database.

According to LIS data, India experienced a similar increase in market income inequality between 2004 and 2011, with Gini index of pre-tax household income rising from 0.49 to 0.52, while the corresponding figures for disposable incomes rose from 0.48 to 0.49 (confirming that in middleand low-income countries the distinction between the two income concepts is conceptually weak-see Section 2). In the case of India, we can only compare the consistency of our results against the WIID database for household consumption, showing that the trends for consumption inequality are very similar between LIS and WIID (see again Figure 8). Income shares indicate a robust expansion of the élites, though it is weaker than what is recorded by corresponding WIID data for the top 10 per cent (see Figure 10). The rising trend would reverse a declining trend detected in the beginning of the previous decade, as a consequence of trade liberalization undertaken by local governments at the end of the previous century (Krishna and Sethupathy

14 In the case of China, the LIS figures for household disposable income inequality are somewhat lower compared to numbers from the external WIID database (due to different equivalency scale applied). Note that trends in both cases are very similar, with the two lines being almost parallel. 
2012). Chancel and Piketty (2017), in a recent working paper, also conclude that economic transformation from a socialist planning to an capitalist economy was the main driver of unequal distribution of income and wealth in India. Over a comparable time interval, we do not find an equivalent trend in income inequality for countries available in the LIS database, since both Taiwan and South Korea exhibit rather stable inequality trends (see graphs presented in Figure A2).

Inequality trends for Russia presented in Figure 8 indicate a declining trend in income inequality, with the Gini index of household disposable income dropping from 41 per cent in 2000 to 33 per cent in $2013 .{ }^{15} \mathrm{~A}$ possible reduction in inequality found in LIS data stands in sharp contrast to results from top incomes analysis: Novokmet et al. (2017) claim that official inequality estimates vastly underestimate the concentration of income in Russia. While income shares of the top 10 per cent exhibit a declining trend in LIS survey data, tax records indicate an opposite trend. ${ }^{16}$ The Russian declining trend in inequality is partly in contrast with other Central and Eastern European countries (Hungary, Poland, and Slovenia), as detectable in Figure A3.

Finally, we consider income inequality trends for South Africa (see again Figure 8). Among all the countries considered in our sample, income inequality in South Africa, measured by all three indices, is by far the highest. Based on the Gini index of DHI, the inequality was as high as 63 per cent in 2008. It gradually dropped to 57 per cent in 2015. As regards consistency with external data sources, we can only compare consumption inequality against the WIID figures. As there are only two points available, we cannot confirm whether the trends are well captured. Nevertheless, one might notice that consumption inequality has opposite trends between 2008 and 2010 based on LIS and WIID figures. When cross-checking with national sources, the problem of data quality (coverage, weights, imputations) emerges immediately, since various data imputation of missing income values may produce alternative trends, though all of them are on the rise. ${ }^{17}$ This is also confirmed by the trend in income shares of the top 10 per cent from WIID, while in the LIS data the corresponding top income share would have lost approximately 10 percentage points. In the case of South Africa, there is no other sub-Saharan country available in the LIS database. The closest country to compare the trends against is Israel, where the ethnic divide is also rather pronounced. Apart from the lower level of aggregate inequality, also in the latter country inequality seems to be declining (see Figure A4).

Overall, we may conclude that the inequality trend in BRICS countries exhibits different patterns, with Latin America and Eastern Europe on a declining trend while Eastern Asia and South Africa are on the rise. Despite the enormous differences in economic structure among these countries, we make an attempt to investigate whether common causes may underlie these changes. We resort to the common within/between decomposition analysis based on the mean log deviation index,

15 As in the case of India, we can only compare the validity of our computed inequality measures for household consumption: Figure 8 shows that consumption inequality computed on LIS data is somewhat lower than corresponding figures from the WIID database.

16 'the Gini coefficient jumped from about 0.3-0.4 in self-reported survey data to over 0.6 using the leaked tax data, and the top $10 \%$ income share moved from about $30 \%$ to over $50 \%$ of total income' (Novokmet et al. 2017: 13).

17 'Using Sequential Regression Multiple Imputation (SRMI) to impute values for reported zero or missing incomes, $\mathrm{Yu}(2009)$ found a strong increase (seven or eight points) in the Gini coefficient between 1996 and 2001 (Table 3). Supporting evidence comes from other studies employing alternative measures: Leibbrandt et al. (2006) found an increase in the Gini from 0.68 to 0.73 using one method, and from 0.74 to 0.79 using another; Simkins (2004) found that the Gini coefficient for households grew from 0.66 to 0.69; and Ardington et al. (2005) concluded that the Gini coefficient rose from 0.74 to 0.82 . There is thus agreement about the trends, though the levels vary widely' (Van Der Berg, 2010: 12). 
and we focus on personal labour earnings, where the identification of common sources of inequality (like gender and education) is easier. In Figure 11 we report the result of such a decomposition, where two covariates are considered, gender and education, and consequently the employed population is divided into six groups (two genders by three educational attainments). The between-group component (the inequality that would have been observed had each group member an income equivalent to the group mean) is intended to capture the return to education and/or the gender gap contributions to inequality: in all countries this dimension declines, though from different starting points. In previously centrally planned economies, this dimension of inequality was almost non-existent, while for the other countries it reached between one-third and one-half of observed earnings inequality. The within-group inequality (namely the inequality that can be attributed to unobserved components) is on the rise in India and South Africa, while a strong reduction can be observed, especially in China. The limit of this approach is the exclusion of people without labour earnings from the analysis, which makes these countries not strictly comparable. Nevertheless, the decomposition indicates that traditional inequality drivers-gender and education - see a reduction of their explanatory power with reference to income inequality.

Figure 11: Inequality decomposition in labour incomes

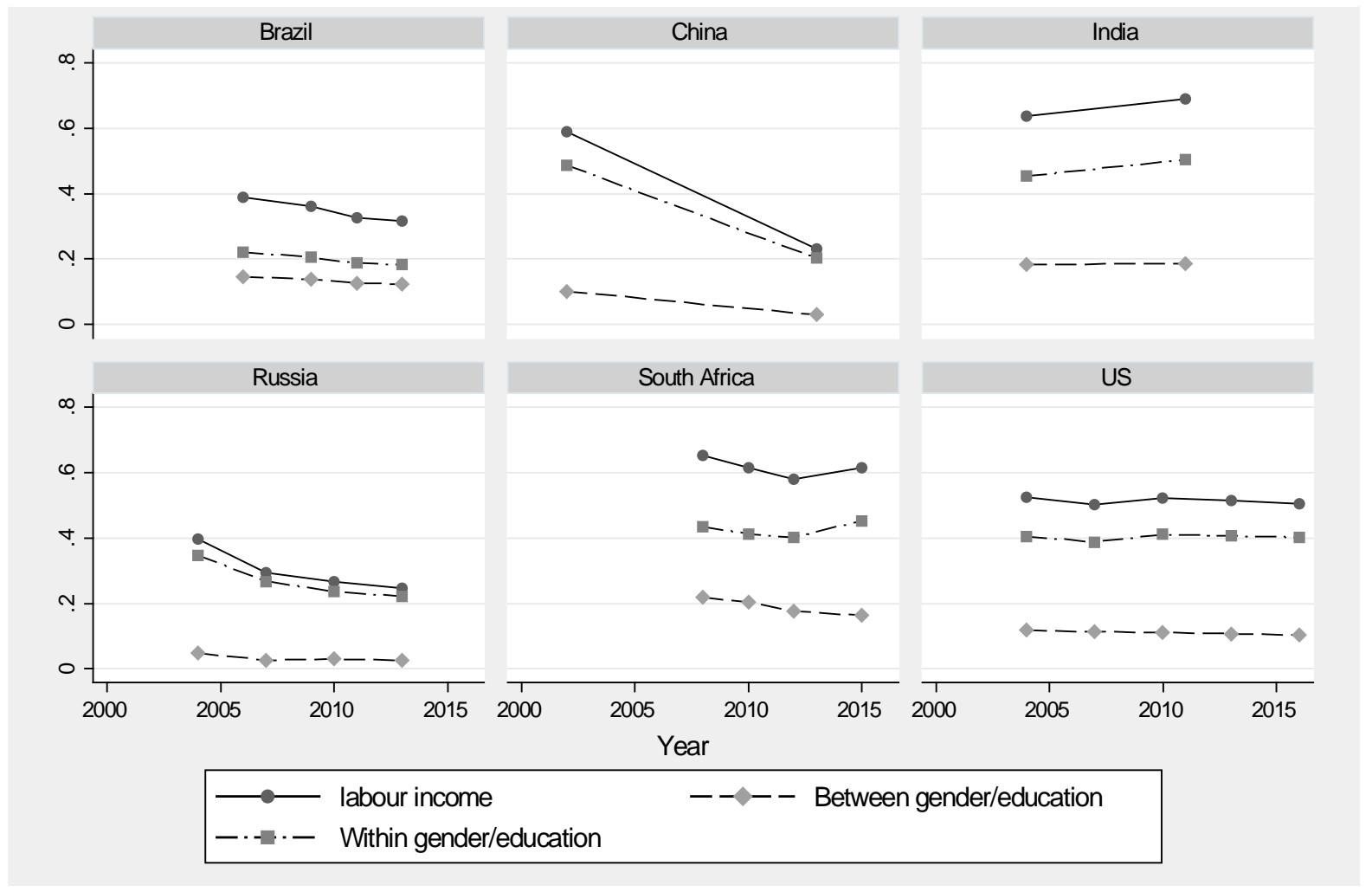

Source: authors, based on data from the LIS database.

\subsection{Regression results}

We now turn to a multivariate analysis, but let us first briefly summarize the main micro and macro indicators that enter our regressions either as outcome variables or covariates. Detailed summary statistics are reported in Table 1. We can see that our countries differ in terms of the computed inequality indicators (e.g. Gini index of the household disposable income ranges from 0.20 to 0.63 ), but also in terms of underlying social conditions (e.g. life expectancy ranges from 53 to 83 years). 
Table 1: Descriptive statistics of variables used in the empirical analysis

\begin{tabular}{|c|c|c|c|c|c|c|}
\hline Variable & Obs. & Countries & Mean & Std. dev. & Min. & Max. \\
\hline Gini index equivalized household factor income & 148 & 21 & 0.43 & 0.08 & 0.27 & 0.71 \\
\hline $\begin{array}{l}\text { Gini index equivalized disposable household } \\
\text { income }\end{array}$ & 150 & 21 & 0.37 & 0.10 & 0.21 & 0.63 \\
\hline $\begin{array}{l}\text { Atkinson index household equivalized factor income } \\
\mathrm{e}=0.5\end{array}$ & 148 & 21 & 0.17 & 0.06 & 0.06 & 0.43 \\
\hline $\begin{array}{l}\text { Atkinson index household equivalized factor income } \\
\mathrm{e}=1\end{array}$ & 148 & 21 & 0.35 & 0.09 & 0.12 & 0.74 \\
\hline $\begin{array}{l}\text { Atkinson index household equivalized factor income } \\
\mathrm{e}=2\end{array}$ & 148 & 21 & 0.82 & 0.13 & 0.31 & 1.00 \\
\hline $\begin{array}{l}\text { Income share bottom } 50 \text { per cent (based on } \\
\text { household factor income) }\end{array}$ & 144 & 21 & 0.19 & 0.05 & 0.03 & 0.30 \\
\hline $\begin{array}{l}\text { Income share top } 10 \text { per cent (based on household } \\
\text { factor income) }\end{array}$ & 147 & 21 & 0.33 & 0.07 & 0.22 & 0.60 \\
\hline $\begin{array}{l}\text { Income share top } 5 \text { per cent (based on household } \\
\text { factor income) }\end{array}$ & 147 & 21 & 0.21 & 0.06 & 0.12 & 0.43 \\
\hline $\begin{array}{l}\text { Income share top } 1 \text { per cent (based on household } \\
\text { factor income) }\end{array}$ & 147 & 21 & 0.07 & 0.03 & 0.03 & 0.17 \\
\hline Gini index personal paid employment income & 143 & 20 & 0.40 & 0.08 & 0.21 & 0.57 \\
\hline Atkinson index personal incomes e $=0.5$ & 143 & 20 & 0.14 & 0.05 & 0.04 & 0.27 \\
\hline Atkinson index personal incomes e = 1 & 143 & 20 & 0.28 & 0.10 & 0.08 & 0.50 \\
\hline Atkinson index personal incomes e $=2$ & 143 & 20 & 0.60 & 0.19 & 0.18 & 0.97 \\
\hline MLD personal paid employment income & 143 & 20 & 0.34 & 0.15 & 0.08 & 0.69 \\
\hline $\begin{array}{l}\text { MLD personal paid employment income-between } \\
\text { six groups (sex and education) }\end{array}$ & 143 & 20 & 0.08 & 0.04 & 0.02 & 0.22 \\
\hline $\begin{array}{l}\text { MLD personal paid employment income-within six } \\
\text { groups (sex and education) }\end{array}$ & 143 & 20 & 0.26 & 0.11 & 0.07 & 0.53 \\
\hline $\begin{array}{l}\text { Decile ratio p90/p10 of personal paid employment } \\
\text { income }\end{array}$ & 143 & 20 & 9.92 & 7.18 & 2.50 & 32.00 \\
\hline Employment rate among men (16-65) & 150 & 21 & 0.72 & 0.09 & 0.40 & 1.00 \\
\hline Employment rate among women (16-65) & 150 & 21 & 0.51 & 0.12 & 0.20 & 1.00 \\
\hline Share female low education 15-65 & 150 & 21 & 0.25 & 0.11 & 0.07 & 0.47 \\
\hline Share female high education 15-65 & 150 & 21 & 0.08 & 0.06 & 0.01 & 0.28 \\
\hline Share male low education 15-65 & 150 & 21 & 0.23 & 0.10 & 0.08 & 0.46 \\
\hline Share male high education 15-65 & 150 & 21 & 0.07 & 0.05 & 0.01 & 0.19 \\
\hline $\begin{array}{l}\text { Age dependency ratio (percentage of working-age } \\
\text { population) }\end{array}$ & 138 & 20 & 0.52 & 0.09 & 0.36 & 0.90 \\
\hline Life expectancy at birth (years) & 138 & 20 & 75.13 & 4.85 & 53.72 & 83.09 \\
\hline Log GDP per capita & 135 & 20 & 9.30 & 0.95 & 6.43 & 10.96 \\
\hline Urban population (percentage of total) & 139 & 20 & 0.73 & 0.13 & 0.29 & 0.95 \\
\hline Government expenditure (percentage of GDP) & 129 & 20 & 0.29 & 0.11 & 0.11 & 0.51 \\
\hline $\begin{array}{l}\text { Government spending on education (percentage of } \\
\text { GDP) }\end{array}$ & 103 & 19 & 4.63 & 0.99 & 2.25 & 6.70 \\
\hline $\begin{array}{l}\text { Agriculture, forestry, and fishing, value added } \\
\text { (percentage of GDP) }\end{array}$ & 122 & 20 & 0.05 & 0.04 & 0.01 & 0.20 \\
\hline $\begin{array}{l}\text { Market capitalization of listed domestic companies } \\
\text { (percentage of GDP) }\end{array}$ & 107 & 19 & 61.96 & 49.29 & 2.08 & 246.47 \\
\hline
\end{tabular}

Source: authors, based on data from the LIS database and the World Bank Indicators database.

We also explore existing correlations between the considered income inequality measure and a set of institutional variables. ${ }^{18}$ We present four scatterplots in Figure 12. The results of these 
unconditional correlations suggest that income inequality (captured by the Gini index of household disposable income) is negatively correlated with the log of GDP per capita (measured in current US dollars), share of public expenditure (percentage of GDP), and life expectancy (years). On the other hand, the age dependency ratio is positively linked with income inequality. This might suggest that in countries with an ageing population and limited replacement pension systems, income inequality becomes an issue. We are fully aware that such graphs do not imply any causal relationships and do not consider potential covariance among these variables. To partly cope with these problems, we move to multivariate regressions.

Figure 12: Income inequality (Gini index) versus selected macroeconomic country characteristics
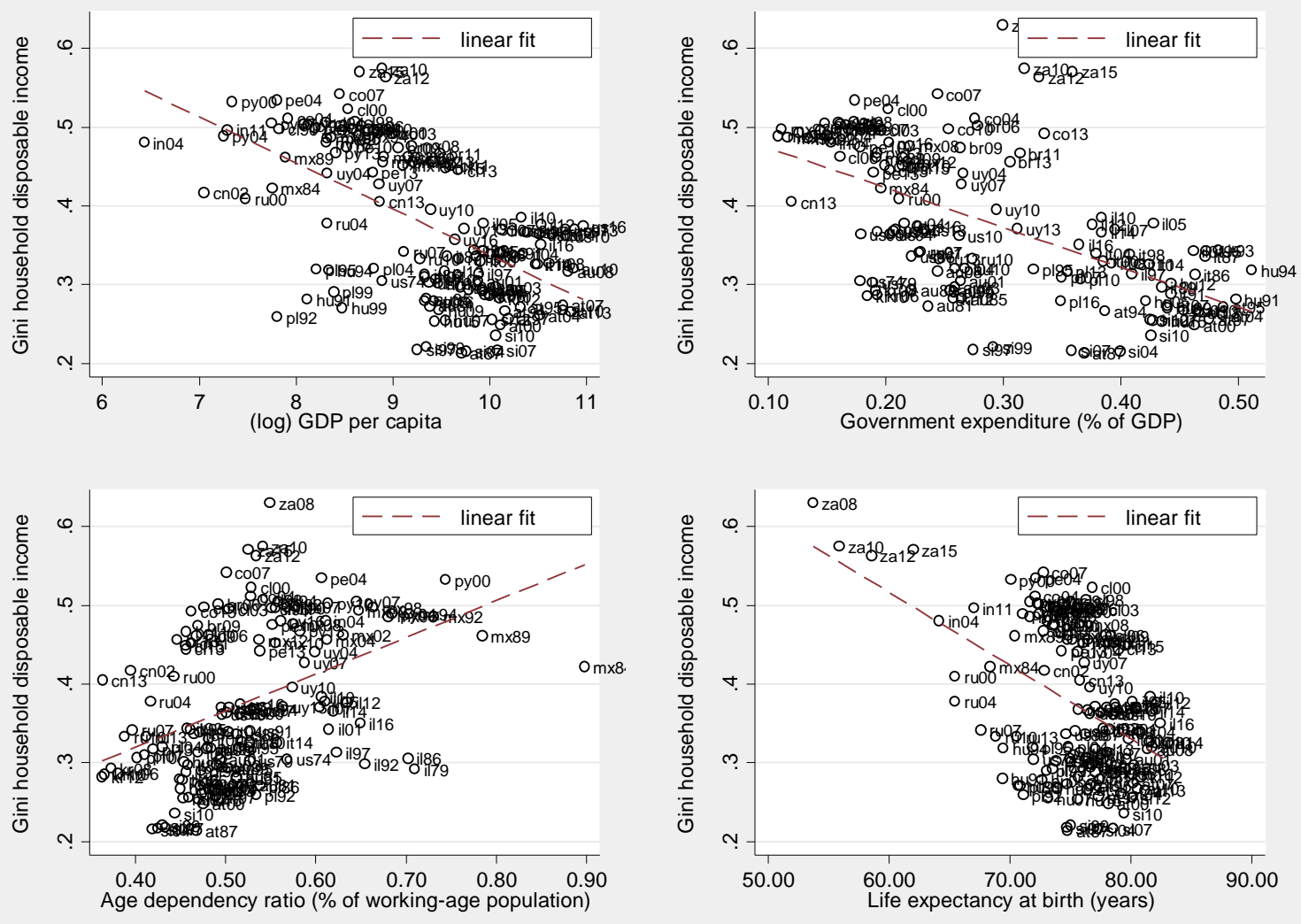

Note: Gini index of DHI (top-coded and equalized according to the OECD equivalence scale) presented on the vertical axis.

Source: authors, based on data from the LIS database and the World Bank Indicators database.

The results of our multivariate analysis are presented in Tables $2-4$. In Table 2 we consider three outcome variables (factor household income, DHI, and personal labour earnings), three inequality indicators (Gini index, Atkinson index with alternative risk aversion coefficients- $\varepsilon=0.5$ and $\varepsilon=2$ - and alternative income shares). Since we do not control for country fixed effects (though residuals are clustered at country level), these are to be intended as simple conditional correlations, meant to explore the data. Among the most persistent results we notice that compositional variables (employment rates and educational attainment by gender) exhibit significant correlations,

per country. The countries are (in brackets the number of surveys): Australia (8), Austria (9), Brazil (4), Chile (12), China (2), Colombia (4), Hungary (8), India (2), Israel (11), Italy (12), South Korea (4), Mexico (12), Paraguay (6), Peru (4), Poland (9), Russia (5), Slovenia (6), South Africa (4), Taiwan (11), the USA (12), and Uruguay (5). 
though with inconsistent patterns. On the contrary, GDP per capita turns out always insignificantly correlated with any inequality measure, similarly to proxies for production composition (agriculture share, trade openness) and public expenditure. Two variables exhibit positive correlation with inequality: one is a proxy for financial development (the market capitalization of listed domestic companies) and the other is a measure of urbanization (though it is positively associated with total income inequality, but negatively associated with labour earnings). However, the main limit of this approach is the missing values on some variables (as can easily be detected in Table 1, where market capitalization and public expenditure are missing in one-third of the sample).

For this reason, in Table 3 we adopt a more parsimonious model, in order to raise the number of observations. We also abandon the Atkinson index (with $\varepsilon=0.5$ ), given its high correlation with the Gini index ( $\rho=0.98$ for household factor income) and we introduce country fixed effects. ${ }^{19}$ We currently find that educational attainment in the male population tends to polarize the income distribution, thus raising inequality, while employment rates reduce it. The GDP per capita and the population urban share are now negatively associated with labour market inequality, though still uncorrelated with total income inequality. However, the timespan covered by these regressions is rather wide, spanning from 1974 to 2016. Therefore, we have chosen to restrict the sample period to most recent observations, in order to obtain a model more compatible with the BRICS sample (which is only observed after the year 2000).

In Table 4 we present our preferred model, which contains a limited number of statistically significant coefficients, especially when looking at inequality in factor incomes or in personal labour earnings. However, more consistent results emerge when considering household disposable incomes (columns 6 and 7 of Table 4), irrespective of whether we use the Gini index or the Atkinson index with $\varepsilon=2$, which focuses more on lower values: inequality declines when more women enter the formal labour market (female employment rate), when public expenditure increases, and when GDP per capita rises ${ }^{20}$

19 Year fixed effects cannot be included since LIS surveys are available in neighbouring years, but not necessarily coincident ones.

20 We have also considered a random-effect model, as well as relaxing the error clustering assumption, without finding more statistical significance in the results. Only life expectancy obtains a significant negative sign, but we acknowledge that causality may go in both directions. 
Table 2: Regression analysis: OLS including all contextual variables

\begin{tabular}{|c|c|c|c|c|c|c|c|c|c|c|c|c|}
\hline \multirow[t]{3}{*}{ Variables } & 1 & 2 & 3 & 4 & 5 & 6 & 7 & 8 & 9 & 10 & 11 & 12 \\
\hline & \multicolumn{6}{|c|}{ Household factor income (labour + capital) } & \multicolumn{3}{|c|}{$\begin{array}{l}\text { Household disposable } \\
\text { income }\end{array}$} & \multicolumn{3}{|c|}{ Personal wage income } \\
\hline & $\begin{array}{l}\text { Gini } \\
\text { index }\end{array}$ & $\begin{array}{l}\text { Atkinson } \\
\mathrm{e}=0.5\end{array}$ & $\begin{array}{l}\text { Atkinson } \\
\mathrm{e}=2\end{array}$ & $\begin{array}{c}\text { share } \\
\text { bottom50 }\end{array}$ & $\begin{array}{l}\text { share } \\
\text { top90 }\end{array}$ & $\begin{array}{l}\text { share } \\
\text { top95 }\end{array}$ & $\begin{array}{c}\text { Gini } \\
\text { index }\end{array}$ & $\begin{array}{c}\text { Atkinson } \\
\mathrm{e}=0.5\end{array}$ & $\begin{array}{c}\text { Atkinson } \\
\mathrm{e}=2\end{array}$ & $\begin{array}{c}\text { Gini } \\
\text { index }\end{array}$ & $\begin{array}{l}\text { Atkinson } \\
\mathrm{e}=2\end{array}$ & p90p10 \\
\hline \multirow[t]{2}{*}{ Employment rate among men (16-65) } & 0.13 & 0.07 & $-0.40^{*}$ & $0.19^{\star \star}$ & 0.09 & 0.09 & 0.26 & 0.19 & -0.24 & $0.63^{\star \star *}$ & $1.28^{\star * \star}$ & $47.16^{\star \star \star}$ \\
\hline & [0.120] & {$[0.106]$} & [0.214] & {$[0.070]$} & {$[0.086]$} & [0.073] & [0.180] & {$[0.117]$} & [0.504] & [0.138] & [0.298] & [10.954] \\
\hline \multirow{2}{*}{$\begin{array}{l}\text { Employment rate among women (16- } \\
65 \text { ) }\end{array}$} & 0.06 & 0.06 & $0.34^{\star *}$ & $-0.15^{\star *}$ & -0.01 & -0.02 & -0.07 & -0.04 & 0.3 & -0.09 & 0.06 & 2.49 \\
\hline & {$[0.114]$} & {$[0.101]$} & [0.133] & [0.061] & {$[0.078]$} & {$[0.062]$} & [0.120] & {$[0.080]$} & {$[0.386]$} & [0.093] & {$[0.227]$} & [13.946] \\
\hline \multirow[t]{2}{*}{ Share female low education 15-65 } & $-1.22^{\star \star \star}$ & $-0.68 * * *$ & 0.76 & 0.41 & $-0.88^{\star \star *}$ & $-0.79 * * *$ & -0.96 & -0.55 & $-2.51^{\star \star \star}$ & $-0.67^{\star \star}$ & 0.35 & -19.8 \\
\hline & {$[0.302]$} & {$[0.230]$} & [0.677] & [0.264] & {$[0.277]$} & [0.199] & {$[0.572]$} & [0.351] & [0.835] & {$[0.254]$} & [0.588] & [45.905] \\
\hline \multirow[t]{2}{*}{ Share female high education 15-65 } & -0.60 ** & $-0.43^{\star *}$ & -0.52 & 0.2 & $-0.39 *$ & $-0.34^{\star}$ & -0.29 & -0.18 & $-1.52^{\star}$ & $-1.05^{\star \star \star}$ & -1.82 & $-85.09 * \star$ \\
\hline & {$[0.236]$} & [0.199] & {$[0.707]$} & [0.225] & [0.213] & [0.174] & {$[0.311]$} & [0.199] & [0.855] & [0.282] & [1.198] & [37.238] \\
\hline \multirow[t]{2}{*}{ Share male low education 15-65 } & $1.25^{\star \star \star}$ & $0.80^{\star \star \star}$ & -0.32 & -0.34 & $0.82^{\star \star \star}$ & $0.75^{\star \star \star}$ & $0.97^{\star}$ & $0.60^{*}$ & $2.40^{\star * \star}$ & $0.67^{\star \star \star}$ & 0.29 & 28.92 \\
\hline & {$[0.290]$} & {$[0.234]$} & {$[0.742]$} & [0.309] & {$[0.275]$} & [0.210] & [0.545] & {$[0.336]$} & [0.658] & [0.191] & [0.773] & [43.557] \\
\hline \multirow[t]{2}{*}{ Share male high education 15-65 } & 0.01 & 0.06 & 0.64 & 0.29 & -0.13 & -0.12 & -0.01 & 0 & 0.99 & $1.71^{\star \star}$ & $4.42^{*}$ & $145.17^{*}$ \\
\hline & [0.330] & [0.243] & {$[0.662]$} & [0.291] & [0.332] & {$[0.286]$} & {$[0.390]$} & [0.252] & {$[0.700]$} & [0.623] & [2.226] & [70.498] \\
\hline \multirow{2}{*}{$\begin{array}{l}\text { Age dependency ratio (percentage of } \\
\text { working-age population) }\end{array}$} & $0.27^{\star \star}$ & $0.14^{\star}$ & $-0.31^{*}$ & $-0.19 * \star \star$ & $0.16^{\star}$ & 0.1 & $0.26^{\star}$ & 0.13 & 0.43 & $0.30^{\star}$ & 0.3 & 29.95 \\
\hline & [0.098] & [0.079] & [0.151] & [0.063] & {$[0.076]$} & [0.059] & {$[0.137]$} & [0.093] & {$[0.363]$} & [0.155] & {$[0.465]$} & [20.890] \\
\hline \multirow[t]{2}{*}{ Life expectancy at birth (years) } & $-0.01^{\star \star \star}$ & $-0.01^{\star *}$ & 0 & $0.00^{\star *}$ & $-0.01^{\star \star \star}$ & $-0.01^{\star \star \star}$ & $-0.01^{\star}$ & $-0.01^{\star}$ & 0 & $-0.01^{\star \star \star}$ & -0.01 & $-0.53^{*}$ \\
\hline & [0.003] & [0.003] & [0.004] & {$[0.002]$} & [0.003] & [0.002] & [0.005] & [0.003] & [0.010] & [0.003] & {$[0.006]$} & {$[0.278]$} \\
\hline \multirow[t]{2}{*}{ Log GDP per capita } & 0.01 & 0.01 & $0.09 * \star$ & 0 & 0 & 0 & -0.02 & -0.02 & 0.02 & 0.01 & 0.04 & 3.24 \\
\hline & {$[0.018]$} & {$[0.016]$} & [0.033] & [0.012] & {$[0.014]$} & [0.013] & [0.023] & {$[0.016]$} & {$[0.065]$} & {$[0.026]$} & {$[0.067]$} & [3.560] \\
\hline \multirow[t]{2}{*}{ Urban population (percentage of total) } & $0.15^{\star \star}$ & 0.07 & -0.17 & $-0.12^{\star \star \star}$ & $0.17^{\star \star}$ & $0.15^{\star \star}$ & $0.17^{*}$ & 0.09 & $-0.32^{*}$ & -0.09 & $-0.71^{\star \star \star}$ & $\frac{-}{32.75^{\star \star \star}}$ \\
\hline & [0.064] & [0.054] & {$[0.116]$} & {$[0.037]$} & [0.062] & {$[0.060]$} & {$[0.082]$} & [0.062] & [0.184] & {$[0.096]$} & [0.192] & [8.638] \\
\hline \multirow{2}{*}{$\begin{array}{l}\text { Government expenditure (percentage } \\
\text { of GDP) }\end{array}$} & -0.08 & 0.03 & 0.06 & 0.08 & -0.07 & -0.06 & -0.11 & -0.03 & -0.14 & $-0.21^{\star *}$ & $-0.40^{*}$ & -8.21 \\
\hline & {$[0.067]$} & [0.049] & {$[0.207]$} & {$[0.050]$} & [0.053] & {$[0.044]$} & [0.133] & {$[0.086]$} & {$[0.255]$} & [0.093] & [0.218] & [13.887] \\
\hline \multirow{3}{*}{$\begin{array}{l}\text { Government spending on education } \\
\text { (percentage of GDP) }\end{array}$} & 0 & 0 & $-0.04^{\star *}$ & -0.01 & 0.01 & 0 & 0 & 0 & $-0.09^{\star}$ & $0.03^{\star \star \star}$ & $0.06^{\star \star}$ & $2.73^{\star \star \star}$ \\
\hline & [0.010] & [0.008] & [0.013] & [0.008] & [0.008] & {$[0.006]$} & [0.015] & [0.009] & [0.047] & [0.006] & [0.023] & [0.752] \\
\hline & 0.2 & -0.07 & -0.02 & $-0.37^{\star}$ & 0.22 & 0.23 & -0.06 & -0.2 & -0.6 & 0.07 & -1.23 & 19.6 \\
\hline
\end{tabular}




\begin{tabular}{|c|c|c|c|c|c|c|c|c|c|c|c|c|}
\hline $\begin{array}{l}\text { Agriculture, forestry, and fishing, value } \\
\text { added (percentage of GDP) }\end{array}$ & [0.314] & [0.268] & [0.644] & [0.181] & [0.293] & [0.284] & [0.522] & [0.362] & [1.155] & {$[0.617]$} & [1.573] & [75.907] \\
\hline Trade openness (percentage of GDP) & $\begin{array}{c}0.02 \\
{[0.028]}\end{array}$ & $\begin{array}{c}0.01 \\
{[0.026]}\end{array}$ & $\begin{array}{c}-0.05 \\
{[0.047]}\end{array}$ & $\begin{array}{c}0 \\
{[0.019]}\end{array}$ & $\begin{array}{c}0.01 \\
{[0.024]}\end{array}$ & $\begin{array}{c}0.01 \\
{[0.024]}\end{array}$ & $\begin{array}{c}0 \\
{[0.039]}\end{array}$ & $\begin{array}{c}0 \\
{[0.027]}\end{array}$ & $\begin{array}{c}-0.27^{\star \star \star} \\
{[0.084]}\end{array}$ & $\begin{array}{c}0.05 \\
{[0.047]}\end{array}$ & $\begin{array}{c}0.16 \\
{[0.094]}\end{array}$ & $\begin{array}{c}6.82 \\
{[5.833]}\end{array}$ \\
\hline $\begin{array}{l}\text { Market capitalization of listed } \\
\text { domestic companies (percentage of } \\
\text { GDP) }\end{array}$ & $\begin{array}{l}0.06^{\star \star \star} \\
{[0.014]}\end{array}$ & $\begin{array}{l}0.05^{\star \star \star} \\
{[0.013]}\end{array}$ & $\begin{array}{c}0.01 \\
{[0.030]}\end{array}$ & $\begin{array}{c}-0.02^{\star \star \star} \\
{[0.007]}\end{array}$ & $\begin{array}{l}0.05^{\star \star \star} \\
{[0.012]}\end{array}$ & $\begin{array}{l}0.04^{\star \star *} \\
{[0.012]}\end{array}$ & $\begin{array}{l}0.08^{\star \star \star} \\
{[0.019]}\end{array}$ & $\begin{array}{l}0.05^{\star \star \star} \\
{[0.014]}\end{array}$ & $\begin{array}{c}0.16^{\star \star} \\
{[0.057]}\end{array}$ & $\begin{array}{l}0.09^{\star \star \star} \\
{[0.025]}\end{array}$ & $\begin{array}{c}0.14^{\star \star} \\
{[0.056]}\end{array}$ & $\begin{array}{c}7.28^{\star \star} \\
{[2.604]}\end{array}$ \\
\hline Observations & 75 & 75 & 75 & 74 & 75 & 74 & 77 & 77 & 77 & 71 & 71 & 71 \\
\hline R-squared & 0.85 & 0.793 & 0.515 & 0.795 & 0.88 & 0.872 & 0.857 & 0.848 & 0.556 & 0.831 & 0.669 & 0.632 \\
\hline
\end{tabular}

Note: Robust standard errors in brackets. Standard errors clustered at country level. ${ }^{\star \star \star} p<0.01,{ }^{\star *} p<0.05,{ }^{*} p<0.1$.

Source: authors, based on the LIS database and World Bank Indicators database. 
Table 3: Regression analysis: country fixed effects selecting some contextual variables

\begin{tabular}{|c|c|c|c|c|c|c|c|c|c|c|}
\hline \multirow[t]{3}{*}{ Variables } & 1 & 2 & \multirow[t]{2}{*}{3} & \multirow[t]{2}{*}{4} & \multirow[t]{2}{*}{5} & \multirow{2}{*}{\multicolumn{2}{|c|}{$\begin{array}{cc}6 & 7 \\
\text { Household } \\
\text { disposable income }\end{array}$}} & 8 & 9 & 10 \\
\hline & \multicolumn{2}{|c|}{$\begin{array}{c}\text { Household factor } \\
\text { income (labour + } \\
\text { capital) }\end{array}$} & & & & & & \multicolumn{3}{|c|}{ Personal wage income } \\
\hline & $\begin{array}{l}\text { Gini } \\
\text { index }\end{array}$ & $\begin{array}{l}\text { Atkinson } \\
\quad \mathrm{e}=2\end{array}$ & $\begin{array}{c}\text { share } \\
\text { bottom5 } \\
0\end{array}$ & $\begin{array}{l}\text { share } \\
\text { top90 }\end{array}$ & $\begin{array}{l}\text { share } \\
\text { top95 }\end{array}$ & $\begin{array}{l}\text { Gini } \\
\text { index }\end{array}$ & $\begin{array}{l}\text { Atkinson } \\
\mathrm{e}=2\end{array}$ & $\begin{array}{l}\text { Gini } \\
\text { index }\end{array}$ & $\begin{array}{l}\text { Atkinson } \\
\mathrm{e}=2\end{array}$ & p90p10 \\
\hline \multirow[t]{2}{*}{ Employment rate among men (16-65) } & $-0.26^{\star \star}$ & 0.12 & $0.18^{\star \star}$ & $-0.19^{*}$ & -0.11 & -0.13 & $-0.71^{\star \star}$ & $-0.34^{\star \star}$ & -0.66 & 3.72 \\
\hline & [0.113] & [0.138] & {$[0.076]$} & [0.101] & {$[0.080]$} & [0.095] & {$[0.325]$} & [0.122] & [0.410] & [15.151] \\
\hline \multirow{2}{*}{$\begin{array}{l}\text { Employment rate among women (16- } \\
65)\end{array}$} & 0.12 & $-0.40^{\star \star *}$ & -0.04 & 0.06 & 0.02 & 0 & 0.26 & $0.28^{\star \star}$ & 0.44 & -1.84 \\
\hline & {$[0.087]$} & {$[0.129]$} & [0.069] & {$[0.082]$} & {$[0.072]$} & [0.079] & [0.220] & [0.120] & {$[0.400]$} & [16.612] \\
\hline \multirow[t]{2}{*}{ Share female low education 15-65 } & 0.14 & -0.48 & -0.12 & 0.14 & $0.19 \star \star$ & 0.02 & -0.86 & 0.13 & -0.13 & -15 \\
\hline & [0.144] & {$[0.426]$} & [0.101] & [0.091] & [0.085] & [0.114] & [0.552] & [0.094] & {$[0.267]$} & [17.744] \\
\hline \multirow[t]{2}{*}{ Share female high education 15-65 } & -0.08 & -0.44 & 0.32 & -0.11 & -0.1 & 0.03 & -0.04 & -0.23 & -0.42 & $92.87^{\star * *}$ \\
\hline & [0.212] & [0.639] & [0.238] & {$[0.213]$} & [0.150] & [0.209] & {$[0.777]$} & [0.160] & [0.778] & [31.871] \\
\hline \multirow[t]{2}{*}{ Share male low education 15-65 } & $0.23^{\star \star}$ & -0.13 & -0.03 & 0.18 & $0.16^{\star}$ & 0.04 & $0.59^{\star \star}$ & 0.08 & -0.42 & -22.99 \\
\hline & [0.102] & [0.161] & {$[0.108]$} & [0.108] & {$[0.087]$} & [0.133] & [0.265] & [0.094] & {$[0.332]$} & [19.263] \\
\hline \multirow[t]{2}{*}{ Share male high education 15-65 } & $0.97^{\star \star \star}$ & 0.99 & $-0.63^{\star \star \star}$ & $0.84^{\star \star \star}$ & $0.70^{\star \star \star}$ & 0.4 & $3.25^{\star \star}$ & $1.09 \star \star \star$ & $3.33^{\star \star \star}$ & $\underset{*}{136.31 * \star}$ \\
\hline & {$[0.177]$} & [1.045] & {$[0.185]$} & [0.175] & {$[0.160]$} & [0.234] & {$[1.278]$} & {$[0.340]$} & {$[0.980]$} & [40.248] \\
\hline \multirow{2}{*}{$\begin{array}{l}\text { Age dependency ratio (percentage of } \\
\text { working-age population) }\end{array}$} & 0.05 & $-0.31^{\star \star}$ & -0.09 & 0.02 & 0.06 & 0.03 & 0.34 & $-0.18^{\star \star}$ & $-0.63^{\star \star \star}$ & $-33.59 * *$ \\
\hline & [0.112] & {$[0.150]$} & [0.122] & [0.112] & {$[0.084]$} & [0.116] & {$[0.417]$} & {$[0.077]$} & {$[0.158]$} & [12.440] \\
\hline \multirow[t]{2}{*}{ Life expectancy at birth (years) } & 0.01 & $0.02^{\star \star}$ & 0 & 0 & 0 & 0 & 0.01 & $0.01^{\star \star}$ & $0.02^{\star \star}$ & $1.62^{\star \star}$ \\
\hline & [0.005] & {$[0.006]$} & [0.004] & {$[0.005]$} & {$[0.004]$} & [0.004] & [0.009] & [0.004] & {$[0.008]$} & {$[0.720]$} \\
\hline \multirow[t]{2}{*}{ Log GDP per capita } & -0.02 & -0.01 & 0.01 & -0.02 & -0.01 & -0.02 & $-0.09^{\star \star}$ & $-0.05^{\star \star}$ & $-0.13^{\star \star \star}$ & $-4.57^{\star \star}$ \\
\hline & {$[0.016]$} & [0.025] & [0.012] & [0.015] & {$[0.014]$} & [0.014] & [0.033] & {$[0.017]$} & {$[0.039]$} & [1.987] \\
\hline \multirow[t]{2}{*}{ Urban population (percentage of total) } & 0.08 & -0.4 & -0.4 & 0.37 & $0.44^{\star \star}$ & 0.06 & -0.12 & $-0.98^{\star \star}$ & $-3.15^{\star \star \star}$ & $\begin{array}{c}- \\
188.85^{\star \star} \\
\end{array}$ \\
\hline & [0.328] & [0.659] & {$[0.311]$} & [0.305] & {$[0.209]$} & [0.305] & [1.072] & {$[0.374]$} & [0.809] & [61.310] \\
\hline $\begin{array}{l}\text { Government expenditure (percentage } \\
\text { of GDP) }\end{array}$ & $-0.19^{\star}$ & -0.2 & -0.03 & -0.15 & -0.11 & -0.12 & -0.51 & -0.12 & -0.07 & 3.18 \\
\hline
\end{tabular}




\begin{tabular}{lcccccccccc}
\hline & {$[0.098]$} & {$[0.220]$} & {$[0.076]$} & {$[0.093]$} & {$[0.075]$} & {$[0.104]$} & {$[0.313]$} & {$[0.125]$} & {$[0.335]$} & {$[15.923]$} \\
Observations & 127 & 127 & 123 & 126 & 126 & 129 & 129 & 122 & 122 & 122 \\
R-squared & 0.289 & 0.271 & 0.326 & 0.234 & 0.216 & 0.179 & 0.331 & 0.373 & 0.332 & 0.311 \\
Number of countries & 21 & 21 & 21 & 21 & 21 & 21 & 21 & 20 & 20 & 20 \\
\hline
\end{tabular}

Note: Robust standard errors in brackets. Standard errors clustered at country level. Country fixed effects included. ${ }^{* \star *} p<0.01,{ }^{* *} p<0.05,{ }^{*} p<0.1$. Source: authors, based on the LIS database and World Bank Indicators database. 
Table 4: Regression analysis: country fixed effects selecting some contextual variables—most recent observations (year $>2000)$

\begin{tabular}{|c|c|c|c|c|c|c|c|c|c|c|}
\hline \multirow[t]{3}{*}{ Variables } & 1 & 2 & 3 & 4 & 5 & 6 & 7 & 8 & 9 & 10 \\
\hline & \multicolumn{5}{|c|}{ Household factor income (labour + capital) } & \multicolumn{2}{|c|}{$\begin{array}{l}\text { Household disposable } \\
\text { income }\end{array}$} & \multicolumn{3}{|c|}{ Personal wage income } \\
\hline & $\begin{array}{l}\text { Gini } \\
\text { index }\end{array}$ & $\begin{array}{l}\text { Atkinson } \\
\mathrm{e}=2\end{array}$ & $\begin{array}{l}\text { share } \\
\text { bottom50 }\end{array}$ & $\begin{array}{l}\text { share } \\
\text { top } 90\end{array}$ & $\begin{array}{l}\text { share } \\
\text { top95 }\end{array}$ & Gini index & $\begin{array}{l}\text { Atkinson } \\
\mathrm{e}=2\end{array}$ & $\begin{array}{l}\text { Gini } \\
\text { index }\end{array}$ & $\begin{array}{l}\text { Atkinson } \\
\mathrm{e}=2\end{array}$ & p90p10 \\
\hline \multirow[t]{2}{*}{ Employment rate among men (16-65) } & 0.11 & 0.54 & 0.07 & 0.1 & 0.13 & 0.16 & 0.37 & -0.06 & -0.42 & 2.05 \\
\hline & {$[0.170]$} & [0.348] & [0.114] & [0.143] & [0.145] & [0.108] & [0.389] & {$[0.146]$} & {$[0.508]$} & [26.774] \\
\hline \multirow[t]{2}{*}{ Employment rate among women (16-65) } & -0.25 & $-0.79^{*}$ & 0.12 & -0.21 & -0.22 & $-0.24^{\star *}$ & $-0.78^{\star \star}$ & 0.05 & 0.07 & 9.72 \\
\hline & {$[0.146]$} & [0.388] & {$[0.115]$} & [0.133] & {$[0.127]$} & [0.092] & {$[0.365]$} & {$[0.166]$} & [0.629] & [32.745] \\
\hline \multirow[t]{2}{*}{ Share female low education 15-65 } & -0.29 & -2.05 & -0.04 & -0.11 & -0.2 & -0.62 & $-5.16^{\star \star \star}$ & -0.08 & -0.68 & -29.26 \\
\hline & [0.565] & [1.984] & {$[0.421]$} & [0.502] & {$[0.474]$} & [0.413] & [1.798] & [0.488] & [2.336] & [83.711] \\
\hline \multirow[t]{2}{*}{ Share female high education 15-65 } & 0.07 & 0.47 & -0.07 & 0.19 & 0.14 & 0.11 & -0.8 & -0.22 & -1.59 & -101 \\
\hline & {$[0.400]$} & {$[1.279]$} & {$[0.286]$} & [0.292] & {$[0.227]$} & [0.261] & [1.124] & [0.731] & [1.956] & {$[130.952]$} \\
\hline \multirow[t]{2}{*}{ Share male low education 15-65 } & 0.11 & 0.11 & 0.14 & 0.18 & 0.31 & 0.43 & 1.66 & -0.33 & -1.65 & -96.12 \\
\hline & {$[0.527]$} & [1.345] & {$[0.357]$} & [0.513] & [0.500] & {$[0.434]$} & {$[1.175]$} & {$[0.450]$} & [1.987] & [66.203] \\
\hline \multirow[t]{2}{*}{ Share male high education 15-65 } & -0.31 & -1.45 & 0.33 & 0.08 & 0.22 & 0.02 & 1.9 & -0.47 & 0.33 & -99.34 \\
\hline & [0.433] & [1.039] & [0.201] & [0.332] & [0.289] & {$[0.347]$} & [1.269] & [0.695] & [2.645] & [100.619] \\
\hline \multirow{2}{*}{$\begin{array}{l}\text { Age dependency ratio (percentage of } \\
\text { working-age population) }\end{array}$} & 0.13 & $-0.86^{*}$ & -0.07 & -0.04 & -0.12 & 0.02 & 0 & 0.4 & $1.31^{*}$ & 66.45 \\
\hline & [0.189] & {$[0.428]$} & {$[0.140]$} & [0.147] & {$[0.116]$} & [0.151] & {$[1.007]$} & {$[0.267]$} & [0.689] & {$[50.825]$} \\
\hline \multirow[t]{2}{*}{ Life expectancy at birth (years) } & 0 & 0.01 & 0 & -0.01 & 0 & 0 & 0 & 0 & 0.01 & 1.04 \\
\hline & [0.005] & [0.008] & [0.004] & [0.005] & {$[0.004]$} & {$[0.003]$} & [0.008] & [0.005] & {$[0.014]$} & {$[0.936]$} \\
\hline \multirow[t]{2}{*}{ Log GDP per capita } & -0.01 & $-0.07^{\star \star \star}$ & 0.01 & -0.01 & -0.01 & $-0.02^{*}$ & $-0.17^{\star \star \star}$ & -0.01 & -0.02 & 1.35 \\
\hline & [0.014] & {$[0.024]$} & [0.008] & [0.013] & [0.011] & {$[0.010]$} & {$[0.049]$} & {$[0.020]$} & {$[0.050]$} & {$[2.713]$} \\
\hline \multirow[t]{2}{*}{ Urban population (percentage of total) } & -0.08 & -0.62 & -0.03 & 0.11 & -0.07 & -0.39 & -0.72 & -0.08 & -0.32 & -137.18 \\
\hline & [0.641] & [1.211] & [0.393] & [0.499] & [0.429] & [0.481] & [1.005] & [0.662] & [1.734] & [105.797] \\
\hline \multirow{2}{*}{$\begin{array}{l}\text { Government expenditure (percentage of } \\
\text { GDP) }\end{array}$} & -0.09 & -0.52 & -0.04 & -0.05 & -0.06 & $-0.17^{\star *}$ & $-0.89^{\star \star}$ & -0.1 & $-0.72^{\star}$ & -2.74 \\
\hline & [0.095] & [0.405] & [0.092] & [0.080] & [0.065] & {$[0.074]$} & {$[0.335]$} & {$[0.157]$} & [0.391] & [21.288] \\
\hline Observations & 83 & 83 & 81 & 83 & 82 & 83 & 83 & 79 & 79 & 79 \\
\hline R-squared & 0.306 & 0.243 & 0.354 & 0.359 & 0.287 & 0.428 & 0.346 & 0.196 & 0.15 & 0.198 \\
\hline Number of countries & 21 & 21 & 21 & 21 & 21 & 21 & 21 & 20 & 20 & 20 \\
\hline
\end{tabular}

Note: Robust standard errors in brackets. Standard errors clustered at country level. Country fixed effects included. ${ }^{\star \star \star} p<0.01,{ }^{\star \star} p<0.05,{ }^{\star} p<0.1$.

Source: authors, based on data from the LIS database and the World Bank Indicators database. 
In this paper we have presented recent developments in income and consumption inequality focusing on a set of middle-income countries (Brazil, China, India, Russia, and South Africa) that have been recently added to the LIS database and for which there is limited coverage and comparability in the empirical literature.

We start by discussing the main challenges when harmonizing income and consumption survey microdata from the middle-income countries and what implications this has for the analysis of economic inequality.

In our empirical exercise, we first estimate a variety of income (consumption) inequality indicators separately for each country and year for the whole population as well as for subpopulation groups. We describe the trends of these five countries against of the trends of neighbouring countries, finding declining trends in inequality in Brazil, Russia, and South Africa, against rising trends in East Asia (India and China).

By then merging inequality indicators with World Bank Indicators data, we create an unbalanced panel database covering around 21 countries over the time period from 1976 to 2016. Our panel data analysis updates the findings of Roine et al. (2009), who estimated macroeconomic determinants of economic inequality for 15 high-income countries.

Results from the country-level panel regressions reveal the following patterns. For our analysed sample of countries, the relationship between income inequality and GDP per capita exhibits a negative correlation, jointly with the (female) employment rate. It is also negatively correlated with public expenditure in GDP, while other controls (like trade openness, share of agriculture, financial openness) come out as not significant when country fixed effect are taken into account. None of the country-level correlation results implies a causal relationship. However, the robustness of the results would be reinforced with more countries available in the sample-especially the lowincome ones which differ in many economic circumstances from the high-income countries. Therefore, in the future the LIS Datacenter aims to acquire more microdata from low- and middleincome countries, in addition to the already covered ones in the database. 


\section{References}

Alvaredo, F., and L. Gasparini (2015). 'Recent Trends in Inequality and Poverty in Developing Countries'. In A.B. Atkinson and F. Bourguignon (eds), Handbook of Income Distribution. Amsterdam: Elsevier.

Ardington, C., D. Lam, M. Leibbrandt, and M. Welch (2005). 'The Sensitivity of Estimates of PostApartheid Changes in South African Poverty and Inequality to Key Data Imputations'. Working Paper 106. Cape Town: Southern Africa Labour and Development Research Unit, University of Cape Town.

Assaad, R., C. Krafft, J. Roemer, and D. Salehi-Isfahani (2016). 'Inequality of Opportunity in Income and Consumption: The Middle East and North Africa Region in Comparative Perspective'. Working Paper 1003. Giza: Economic Research Forum.

Assaad, R., C. Krafft, H. Nazier, R. Ramadan, A. Vahidmanesh, and S. Zouari (2017). 'Estimating Poverty and Inequality in the Absence of Consumption Data: An Application to the Middle East and North Africa'. Working Paper 1100. Giza: Economic Research Forum.

Atkinson, A. B., and A. Brandolini (2001). 'Promise and Pitfalls in the Use of "Secondary" Datasets: Income Inequality in OECD Countries as a Case Study'. Journal of Economic Literature, 39(3): 771-99.

Atkinson, A. B., T. Piketty, and E. Saez (2011). 'Top Incomes in the Long Run of History'. Journal of Economic Literature, 49(1): 3-71.

Chancel, L., and T. Piketty (2017). 'Indian Income Inequality, 1922-2014: From British Raj to Billionaire Raj?'. Discussion Paper 12409. Washington, DC: CEPR.

Cornia, G.A. (ed.) (2014). Falling Inequality in Latin America: Policy changes and Lessons. Oxford: Oxford University Press.

Cowell, F. (2011). Measuring Inequality. Oxford: Oxford University Press.

Davies, J. B., R. Lluberas, and A.F. Shorrocks (2017). 'Estimating the Level and distribution of Global wealth, 2000-2014'. Review of Income and Wealth, 63(4): 731-59.

Evans, M., A. Hidalgo, and M. Wang (2018). 'Universal Child Allowances in 14 Middle Income Countries: Options for Policy and Poverty Reduction’. Working Paper 738. Esch-Belval: LIS Cross-National Data Center in Luxembourg.

Gasparini, L., G. Cruces, L. Tornarolli, and D. Mejía (2011). 'Recent Trends in Income Inequality in Latin America [with Comments]'. Economia, 11(2), 147-201.

Gornick, J.C., M. Jantti, and A. Leguizamon (2009). 'Adding Five Latin American Datasets to the Luxembourg Income Study (LIS) Database: Data Assessment and First Comparative Results'. Technical Paper 3. Esch-Belval: LIS Cross-National Data Center in Luxembourg.

Ghosh, M. (2012). 'Regional Economic Growth and Inequality in India during the Pre- and PostReform Periods'. Oxford Development Studies, 40(2): 190-212.

Jain-Chandra, S., N. Khor, R. Mano, J. Schauer, P. Wingender and J. Zhuang. (2018). 'Inequality in China: Trends, Drivers and Policy Remedies'. Working Paper 18/127. Washington, DC: IMF.

Krishna, P. and G. Sethupathy. (2012). 'Trade and Income Inequality in India'. In J. Bhagwati and A. Panagariya (eds), India's Reforms: How They Produced Inclusive Growth. Oxford: Oxford University Press. 
Lakner, C., and B. Milanovic (2016). 'Global Income Distribution: From the Fall of the Berlin Wall to the Global Recession'. World Bank Economic Review, 30: 203-32.

Leibbrandt, M., L. Poswell, P. Naidoo, M. Welch, and I. Woolard (2006). 'Measuring Recent Changes in South African Inequality and Poverty Using 1996 and 2001 Census Data'. In H. Bhorat and R. Kanbur (eds), Poverty and Policy in Post-Apartheid South Africa. Cape Town: HSRC Publishing.

LIS (n.d.). Luxembourg Income Study. Database. Esch-Belval: LIS Cross-National Data Center in Luxembourg.

Lustig, N., L.F. Lopez-Calva, and E. Ortiz-Juarez (2013). 'Declining Inequality in Latin America in the 2000s: The Cases of Argentina, Brazil, and Mexico'. World Development, 44(C): 129-41.

Novokmet, F., T. Piketty, and G. Zucman (2017). 'From Soviets to Oligarchs: Inequality and Property in Russia, 1905-2016'. Working Paper 23712. Cambridge, MA: NBER.

Piketty, T., and N. Qian (2009). 'Income Inequality and Progressive Income Taxation in China and India, 1986-2015'. American Economic Journal: Applied Economics, 1(2): 53-63.

Rasch, R. (2017). 'Measuring the Middle Class in Middle-Income Countries'. Forum for Social Economics, 46(4), 321-36.

Roine, J., J. Vlachos, and D. Waldenström (2009). 'The Long-Run Determinants of Inequality: What Can We Learn from Top Income Data?'. Journal of Public Economics, 93(7-8): 974-88.

Simkins, C. (2004). 'What Happened to the Distribution of Income in South Africa between 1995 and 2001'. Johannesburg: University of the Witwatersrand.

Van Der Berg, S. (2010). 'Current Poverty and Income Distribution in the Context of South Africa History'. Working Paper 22/10. Stellenbosch: Stellenbosch University, Department of Economics.

World Bank (n.d.). World Development Indicators. Database. Washington, DC: The World Bank. Available at: https://data.worldbank.org.

Yu, D. (2009). 'The Comparability of Census 1996, Census 2001 and Community Survey 2007'. Working Paper 21/2009. Stellenbosch: Stellenbosch University, Department of Economics. 
Appendix: additional tables and figures

Table A1: Overview of sample countries used in the empirical analysis

\begin{tabular}{|c|c|c|c|c|c|c|c|c|c|c|c|}
\hline Country & $\begin{array}{c}\text { Historical } \\
\text { data }\end{array}$ & $\begin{array}{l}\text { Wave I } \\
(\sim 1980)\end{array}$ & $\begin{array}{l}\text { Wave II } \\
(\sim 1985) \\
\end{array}$ & $\begin{array}{l}\text { Wave III } \\
(\sim 1990)\end{array}$ & $\begin{array}{l}\text { Wave IV } \\
(\sim 1995) \\
\end{array}$ & $\begin{array}{l}\text { Wave V } \\
(-2000)\end{array}$ & $\begin{array}{l}\text { Wave VI } \\
(-2004)\end{array}$ & $\begin{array}{c}\text { Wave VII } \\
(\sim 2007)\end{array}$ & $\begin{array}{c}\text { Wave VIII } \\
(-2010)\end{array}$ & $\begin{array}{l}\text { Wave IX } \\
(\sim 2013)\end{array}$ & $\begin{array}{l}\text { Wave X } \\
(\text { 2016) }\end{array}$ \\
\hline Austria (AT) & n.a. & n.a. & AT 87 & n.a. & $\begin{array}{l}\text { AT } 94 \\
\text { AT } 95 \\
\text { AT } 97\end{array}$ & AT 00 & AT 04 & AT 07 & AT 10 & AT 13 & n.a. \\
\hline Australia (AU) & n.a. & $A \cup 81$ & AU 85 & AU 98 & AU 95 & $A \cup 01$ & $A \cup 03$ & $A \cup 08$ & $\mathrm{AU} 10$ & n.a. & n.a. \\
\hline Brazil (BR) & n.a. & n.a. & n.a. & n.a. & n.a. & n.a. & n.a. & BR 06 & $\begin{array}{l}\text { BR } 09 \\
\text { BR } 11\end{array}$ & BR 13 & n.a. \\
\hline Chile (CL) & n.a. & n.a. & n.a. & $\begin{array}{l}\text { CL } 90 \\
\text { CL } 92\end{array}$ & $\begin{array}{l}\text { CL } 94 \\
\text { CL } 96\end{array}$ & $\begin{array}{l}\text { CL } 98 \\
\text { CL } 00\end{array}$ & CL 03 & CL 06 & $\begin{array}{l}\text { CL } 09 \\
\text { CL } 11\end{array}$ & CL 13 & CL 15 \\
\hline China $(\mathrm{CN})$ & n.a. & n.a. & n.a. & n.a. & n.a. & $\mathrm{CN} 02$ & n.a. & n.a. & n.a. & $\mathrm{CN} 13$ & n.a. \\
\hline Colombia (CO) & n.a. & n.a. & n.a. & n.a. & n.a. & n.a. & CO 04 & $\mathrm{CO} 07$ & CO 10 & $\mathrm{CO} 13$ & n.a. \\
\hline India (IN) & n.a. & n.a. & n.a. & n.a. & n.a. & n.a. & IN 04 & n.a. & IN 11 & n.a. & n.a. \\
\hline Israel (IL) & n.a. & IL 79 & IL 86 & IL 92 & IL 97 & IL 01 & IL 05 & IL 07 & IL 10 & $\begin{array}{l}\text { IL } 12 \\
\text { IL } 14\end{array}$ & IL 16 \\
\hline Italy (IT) & n.a. & n.a. & $\begin{array}{l}\text { IT } 86 \\
\text { IT } 87\end{array}$ & $\begin{array}{l}\text { IT } 89 \\
\text { IT } 91\end{array}$ & $\begin{array}{l}\text { IT } 93 \\
\text { IT } 95\end{array}$ & $\begin{array}{l}\text { IT } 98 \\
\text { IT } 00\end{array}$ & IT 04 & IT 08 & IT 10 & IT 14 & n.a. \\
\hline Mexico (MX) & n.a. & n.a. & MX 84 & $\begin{array}{l}\text { MX } 89 \\
\text { MX } 92\end{array}$ & $\begin{array}{l}\text { MX } 94 \\
\text { MX } 96\end{array}$ & $\begin{array}{l}\text { MX } 98 \\
M X 00 \\
M X 02\end{array}$ & MX 04 & MX 08 & $M \times 10$ & $\mathrm{MX} 12$ & n.a. \\
\hline Paraguay (PY) & n.a. & n.a. & n.a. & n.a. & n.a. & PY 00 & PY 04 & PY 07 & PY 10 & PY 13 & PY 16 \\
\hline Peru (PE) & n.a. & n.a. & n.a. & n.a. & n.a. & n.a. & PE 04 & PE 07 & PE 10 & PE 13 & n.a. \\
\hline Poland (PL) & n.a. & n.a. & PL 86 & PL 92 & PL 95 & PL 99 & PL 04 & PL 07 & PL 10 & PL 13 & PL 16 \\
\hline Russia (RU) & n.a. & n.a. & n.a. & n.a. & n.a. & $\mathrm{RU} 00$ & $\mathrm{RU} 04$ & $\mathrm{RU} 07$ & $\mathrm{RU} 10$ & $\mathrm{RU} 13$ & n.a. \\
\hline Slovenia (SI) & n.a. & n.a. & n.a. & n.a. & SI 97 & SI 99 & SI 04 & SI 07 & SI 10 & SI 12 & n.a. \\
\hline South Africa (ZA) & n.a. & n.a. & n.a. & n.a. & n.a. & n.a. & n.a. & ZA 08 & ZA 10 & ZA 12 & ZA 15 \\
\hline South Korea (KR) & n.a. & n.a. & n.a. & n.a. & n.a. & n.a. & KR 06 & KR 08 & KR 10 & KR 12 & n.a. \\
\hline
\end{tabular}




\begin{tabular}{|c|c|c|c|c|c|c|c|c|c|c|c|}
\hline Taiwan (TW) & n.a. & TW 81 & TW 86 & TW 91 & $\begin{array}{l}\text { TW } 95 \\
\text { TW } 97\end{array}$ & TW 00 & TW 05 & TW 07 & TW 10 & TW 13 & TW 16 \\
\hline United States (US) & US 74 & US 79 & US 86 & US 91 & $\begin{array}{l}\text { US } 94 \\
\text { US } 97\end{array}$ & US 00 & US 04 & US 07 & US 10 & US 13 & US 16 \\
\hline Uruguay (UY) & n.a. & n.a. & n.a. & n.a. & n.a. & n.a. & UY 04 & UY 07 & UY 10 & UY 13 & UY 16 \\
\hline
\end{tabular}

Note: countries with microdata not available are labelled as 'n.a.'.

Source: authors, based on the LIS database. 
Table A2: Description of micro-variables used in the empirical analysis

\begin{tabular}{|c|c|c|}
\hline Variable & LIS codes & Description \\
\hline Market income & FACTOR & Total current monetary and non-monetary income from labour and capital \\
\hline $\begin{array}{l}\text { Disposable } \\
\text { household } \\
\text { income }\end{array}$ & $\mathrm{HI}-\mathrm{HXIT}$ & $\begin{array}{l}\text { Total monetary and non-monetary current income net of income taxes and social } \\
\text { security contributions }\end{array}$ \\
\hline $\begin{array}{l}\text { Household } \\
\text { monetary } \\
\text { consumption }\end{array}$ & HMC & $\begin{array}{l}\text { Total consumption from expenditures (monetary consumption), that is consumption } \\
\text { of goods and services that have been purchased by the household }\end{array}$ \\
\hline $\begin{array}{l}\text { Total individual } \\
\text { income }\end{array}$ & PILE & $\begin{array}{l}\text { Paid employment personal income. This includes monetary payments and value of } \\
\text { non-monetary goods and services received from regular and irregular dependent } \\
\text { employment }\end{array}$ \\
\hline Education & EDUC & $\begin{array}{l}\text { Recode of the highest completed level of education into three categories: } \\
\text { - low: less than secondary education completed (never attended, no completed } \\
\text { education or education completed at the ISCED levels } 0,1 \text {, or } 2 \text { ) } \\
\text { - medium: secondary education completed (completed ISCED levels } 3 \text { or } 4 \text { ) } \\
\text { - high: tertiary education completed (completed ISCED levels } 5 \text { or } 6 \text { ) }\end{array}$ \\
\hline $\begin{array}{l}\text { Employment } \\
\text { status }\end{array}$ & EMP & Indicator of any employment activity in the current period \\
\hline Gender & SEX & Classification of persons according to their sex \\
\hline Age & AGE & $\begin{array}{l}\text { Age in years. Note that when original data provide age in intervals, values given } \\
\text { are the lowest value of the interval. For example, the intervals 10-14 and 15-19 } \\
\text { will be coded as } 10 \text { and 15, respectively }\end{array}$ \\
\hline Household size & NHHMEM & $\begin{array}{l}\text { Number of household members. Note that in most datasets this corresponds to the } \\
\text { number of persons in the survey unit }\end{array}$ \\
\hline Weight & HPOPWGT & $\begin{array}{l}\text { Population household cross-sectional weight: this weight inflates the result to } \\
\text { reflect the total household population covered by the dataset }\end{array}$ \\
\hline
\end{tabular}

Source: METIS (METadata Information System) of the Luxembourg Income Study Database (www.lisdatacenter.org/frontend\#/home). 
Table A3: Description of institutional variables used in the country-level analysis

\begin{tabular}{ll}
\hline Variable & Description \\
\hline GDP per capita & GDP per capita is gross domestic product divided by mid-year population. \\
GDP is the sum of gross value added by all resident producers in the \\
economy plus any product taxes and minus any subsidies not included in the \\
value of the products. It is calculated without making deductions for \\
depreciation of fabricated assets or for depletion and degradation of natural
\end{tabular}

Agriculture, forestry, and fishing, value Agriculture corresponds to International Standard Industrial Classification added (percentage of GDP)

(ISIC) divisions 1-5 and includes forestry, hunting, and fishing, as well as cultivation of crops and livestock production. Value added is the net output of a sector after adding up all outputs and subtracting intermediate inputs. It is calculated without making deductions for depreciation of fabricated assets or depletion and degradation of natural resources. The origin of value added is determined by the ISIC, revision 3 .

Age dependency ratio (percentage of working-age population)

Age dependency ratio is the ratio of dependents (people younger than 15 or older than 64) to the working-age population (those aged 15-64). Data are shown as the proportion of dependents per 100 working-age population.

Market capitalization of listed domestic Market capitalization (also known as market value) is the share price times companies (percentage of GDP) the number of shares outstanding (including their several classes) for listed domestic companies. Investment funds, unit trusts, and companies whose only business goal is to hold shares of other listed companies are excluded. Data are end of year values.

Imports of goods and services (percentage of GDP)

Imports of goods and services represent the value of all goods and other market services received from the rest of the world. They include the value of merchandise, freight, insurance, transport, travel, royalties, licence fees, and other services, such as communication, construction, financial, information, business, personal, and government services. They exclude compensation of employees and investment income (formerly called factor services) and transfer payments.

Exports of goods and services (percentage of GDP)

Exports of goods and services represent the value of all goods and other market services provided to the rest of the world. They include the value of merchandise, freight, insurance, transport, travel, royalties, licence fees, and other services, such as communication, construction, financial, information, business, personal, and government services. They exclude compensation of employees and investment income (formerly called factor services) and transfer payments.

Government expenditure

Expense is cash payments for operating activities of the government in providing goods and services. It includes compensation of employees (such as wages and salaries), interest and subsidies, grants, social benefits, and other expenses such as rent and dividends.

Life expectancy

Life expectancy at birth indicates the number of years a newborn infant would live if prevailing patterns of mortality at the time of its birth were to stay the same throughout its life.

Urban population (percentage of the Urban population refers to people living in urban areas as defined by total population) national statistical offices.

Source: authors, based on the World Development Indicators, World Bank. 
Figure A1: Inequality trends and evolution of income shares in Latin America

Household equivalised income/consumption - Gini indices

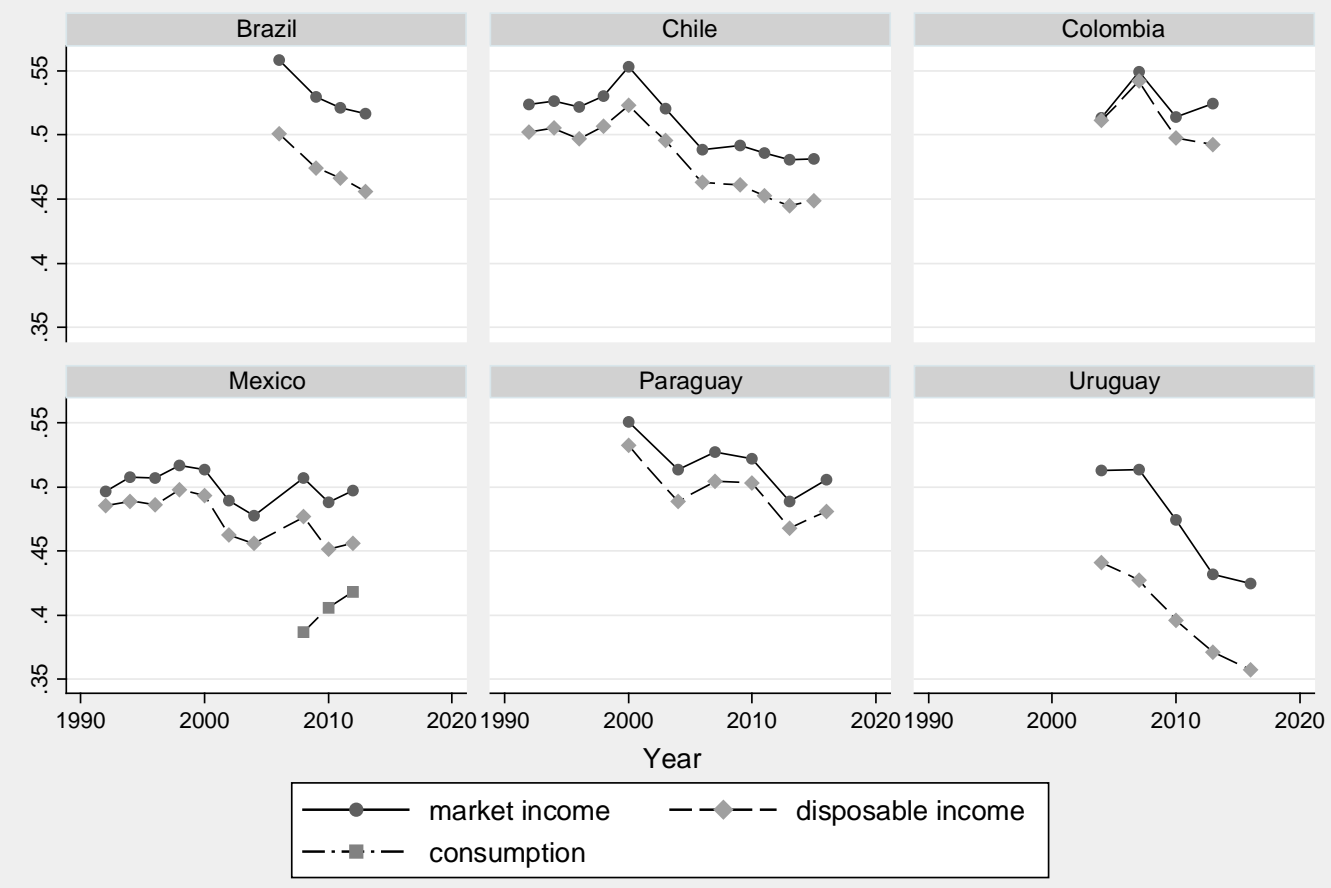

Market income shares

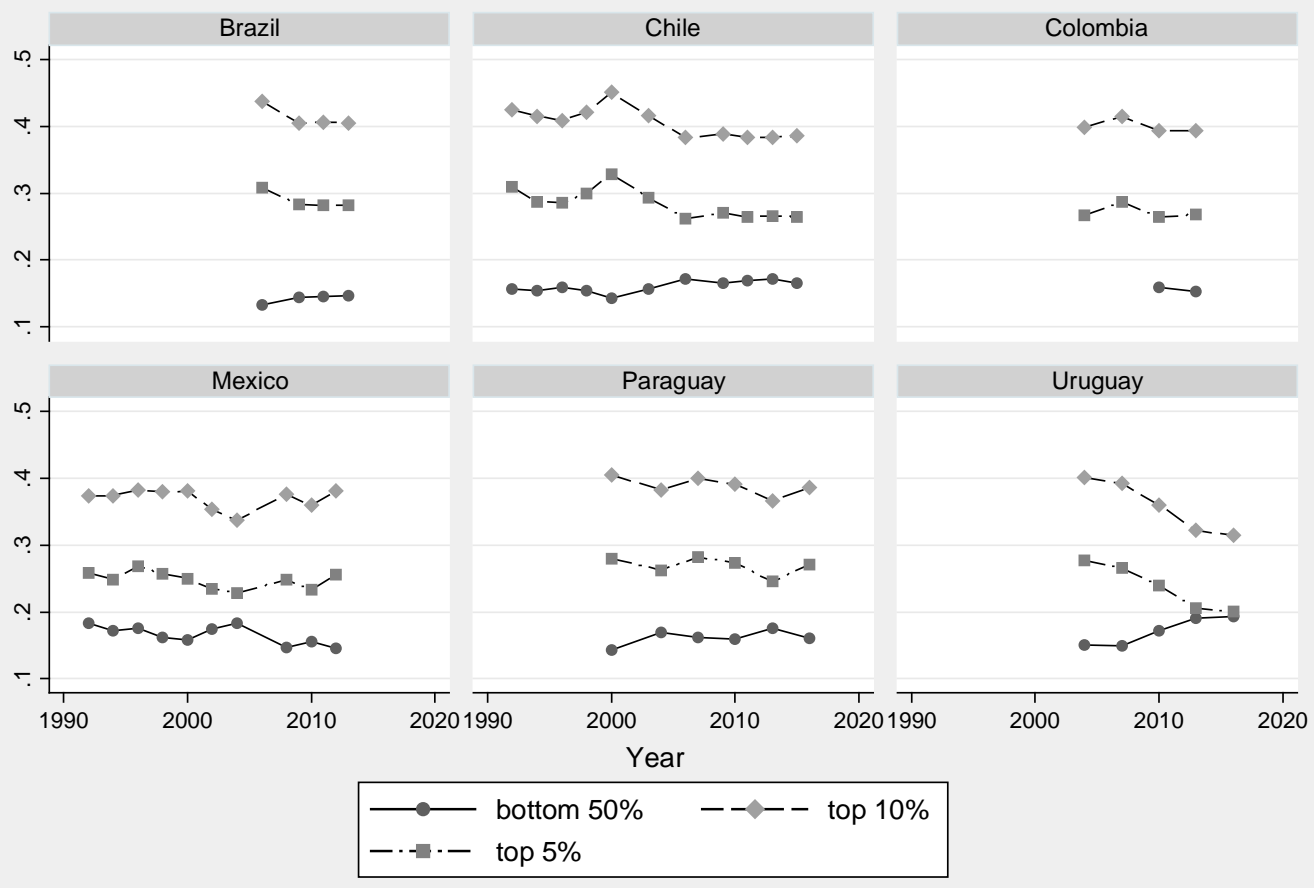

Source: authors, based on data from the LIS database. 
Figure A2: Inequality trends and evolution of income shares in Southeast Asia

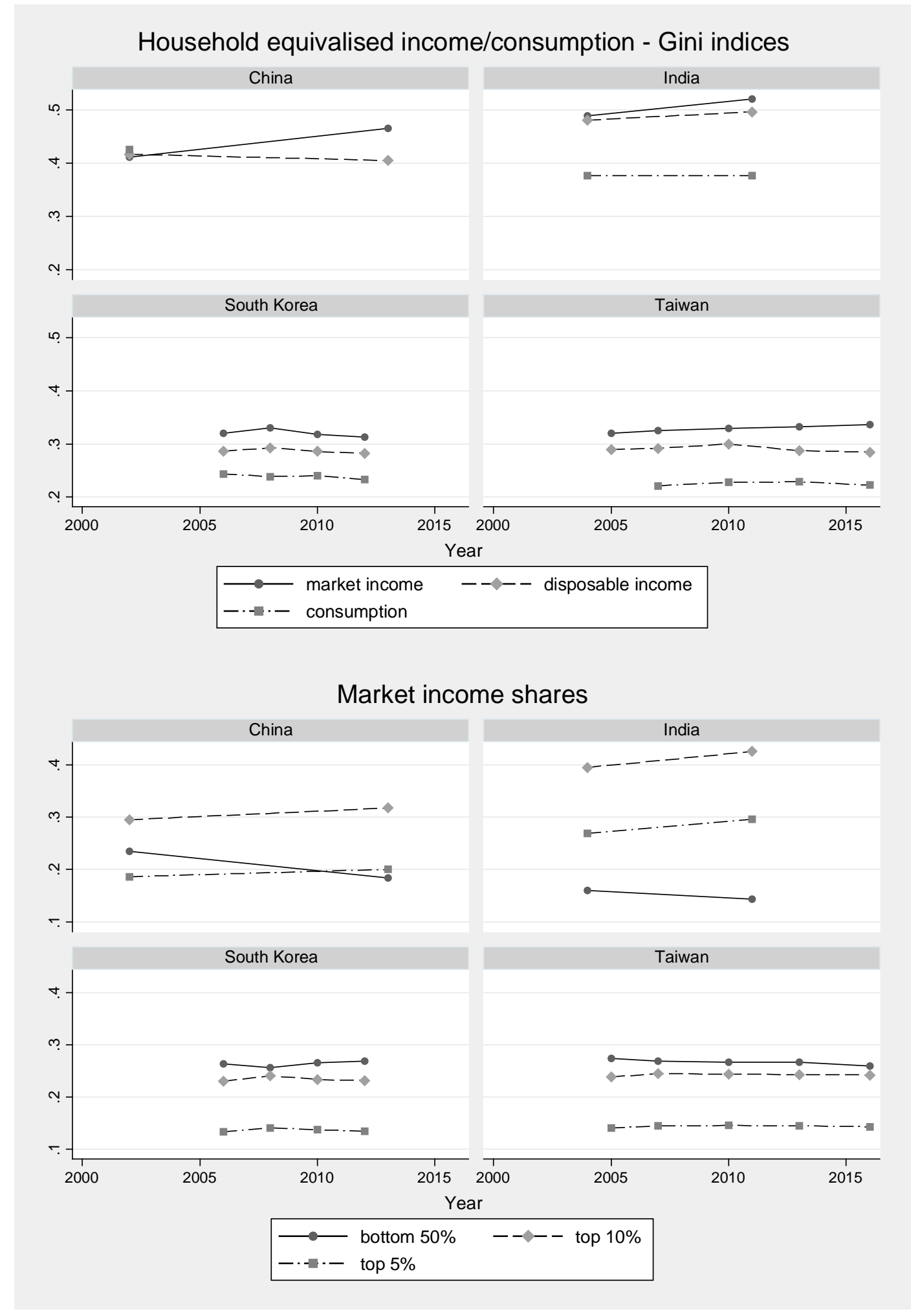

Source: authors, based on data from the LIS database. 
Figure A3: Inequality trends and evolution of income shares in Central and Eastern Europe

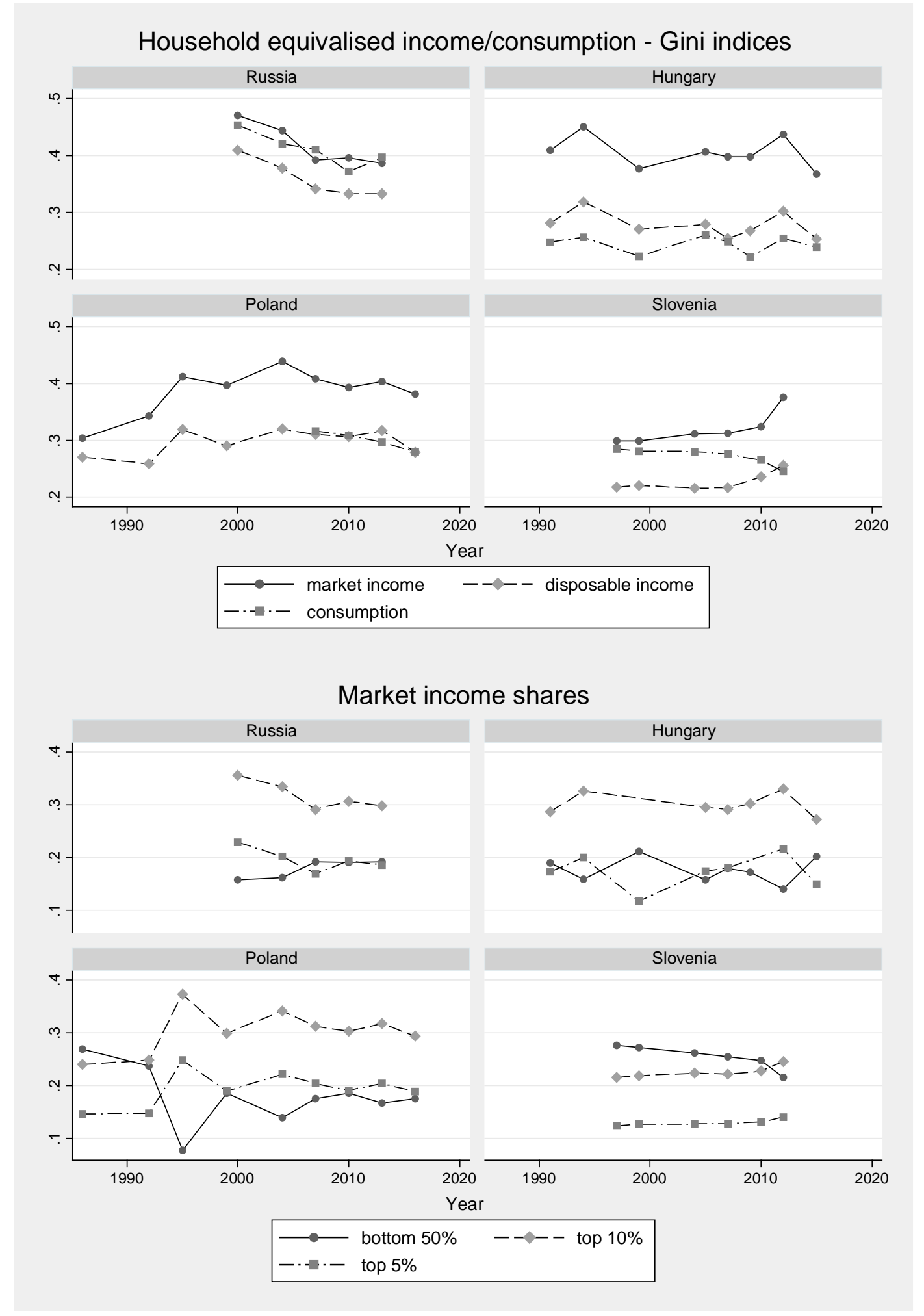

Source: authors, based on data from the LIS database. 
Figure A.4: Inequality trends and evolution of income shares in South Africa and Israel
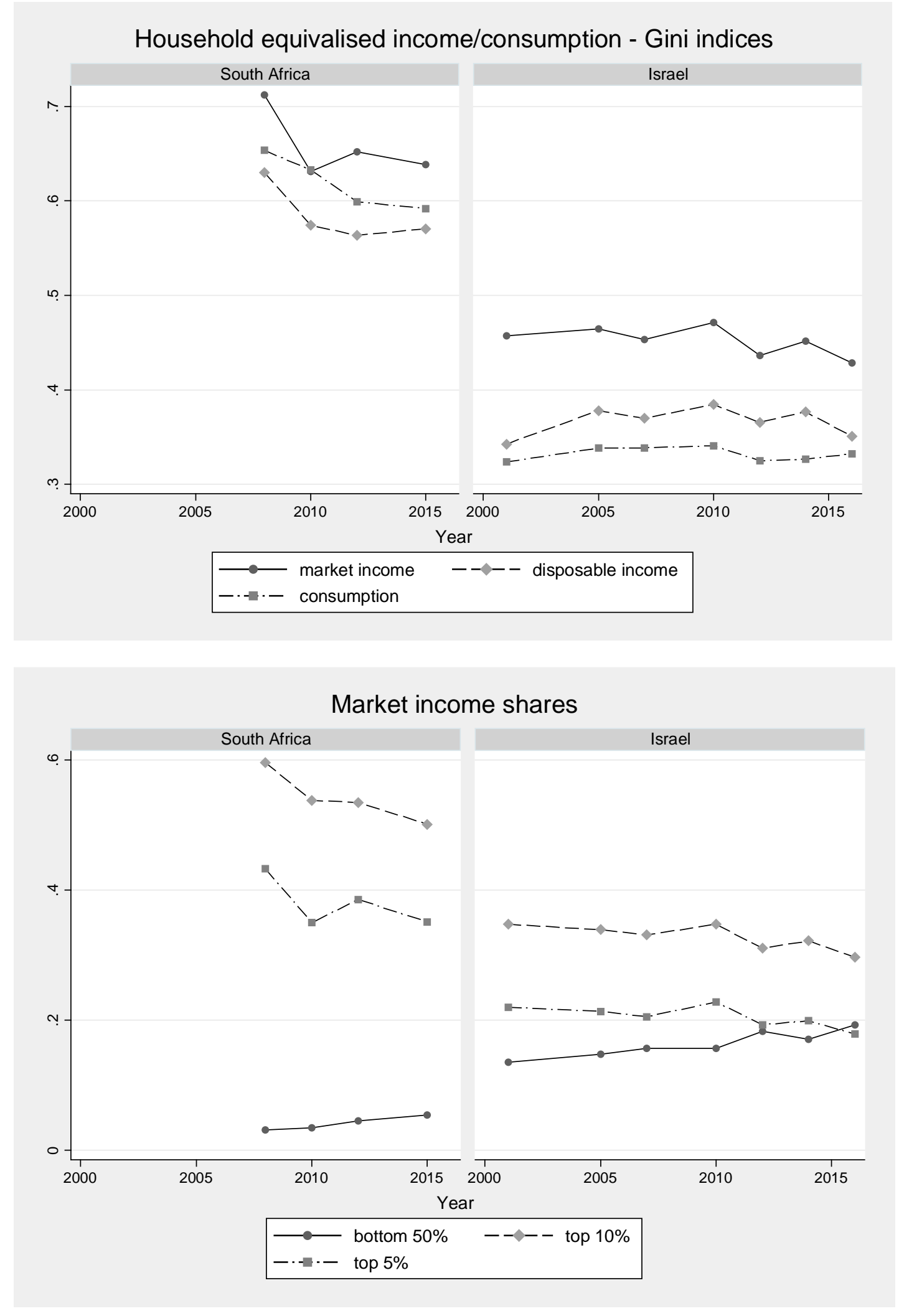

Source: authors, based on data from the LIS database. 